\title{
Excavation of a Bronze Age funerary site at Loth Road, Sanday, Orkney
}

\author{
by Paul M Sharman
}

with contributions by Diane Alldritt, Ann Clarke, Ann MacSween, Effie Photos-Jones \& Julie Roberts 
Published by the Society of Antiquaries of Scotland, www.socantscot.org.uk with Historic Scotland, www.historic-scotland.gov.uk and the Council for British Archaeology, www.britarch.ac.uk

Editor Debra Barrie

Produced by Archetype Information Technology Ltd, www.archetype-it.com

ISBN: 0903903954

ISSN: $1473-3803$

Requests for permission to reproduce material from a $S A I R$ report should be sent to the Director of the Society of Antiquaries of Scotland, as well as to the author, illustrator, photographer or other copyright holder.

Copyright in any of the Scottish Archaeological Internet Reports series rests with the SAIR Consortium and the individual authors.

The maps are reproduced from Ordnance Survey material with the permission of Ordnance Survey on behalf of The Controller of Her Majesty's Stationery Office. (C) Crown copyright 2001. Any unauthorized reproduction infringes Crown copyright and may lead to prosecution or civil proceedings. Historic Scotland Licence No GD 03032G, 2002.

The consent does not extend to copying for general distribution, advertising or promotional purposes, the creation of new collective works or resale. 


\section{Contents}

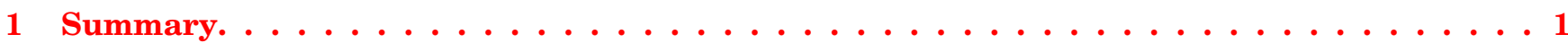

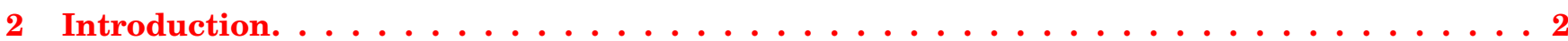

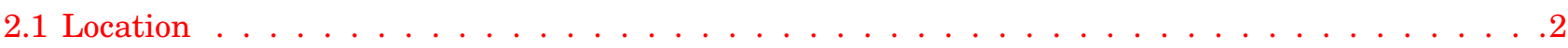

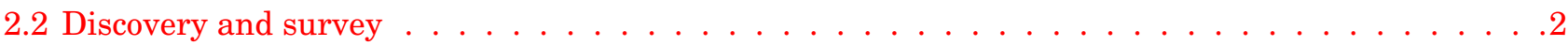

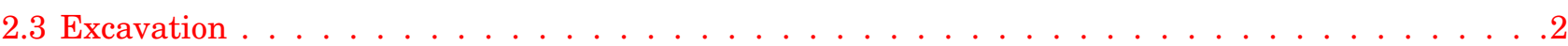

3 Excavation Results. ........................... 4

3.1 Structure $1 \ldots \ldots \ldots \ldots \ldots \ldots \ldots \ldots \ldots \ldots \ldots \ldots \ldots$

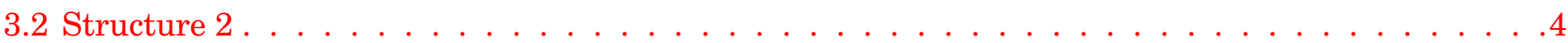

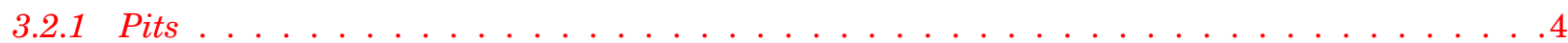

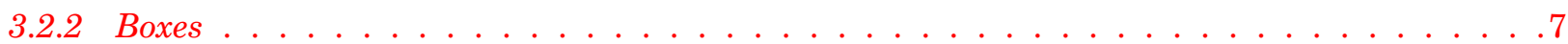

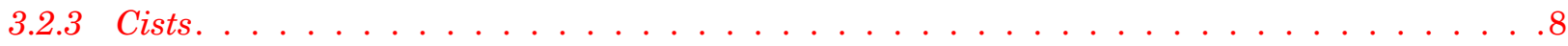

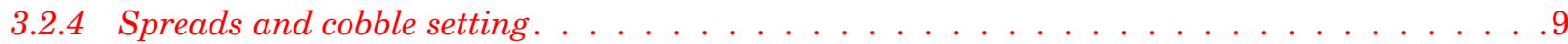

3.2 .5 The kerb. . . . . . . . . . . . . . . . . . . . . . . . . 10

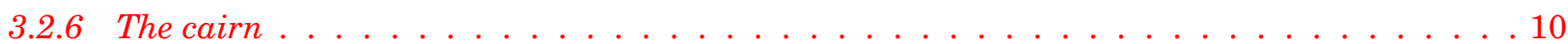

4 The Cremated Human Remains by Julie A Roberts . . . . . . . . . . . . . . . . . . . . .11

4.1 Introduction . . . . . . . . . . . . . . . . . . . . . . . 11

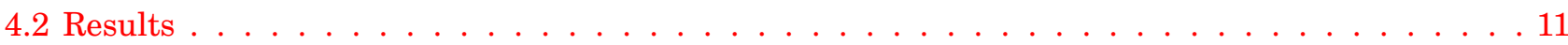

4.2.1 Species and minimum numbers of individuals $(\mathrm{MNI})$ present . . . . . . . . . . . . . 11

4.2 .2 Age at death and sex . . . . . . . . . . . . . . . . . . . . 11

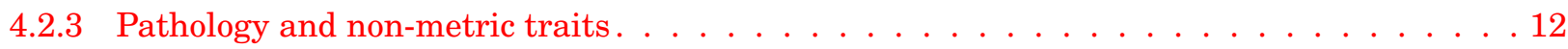

4.2 .4 Mortuary practice . . . . . . . . . . . . . . . . . . . . . 12

5 Identification and Analysis of Carbonized Plant Remains by Diane Alldritt . . . . . . . . . 14

5.1 Introduction . . . . . . . . . . . . . . . . . . . . . . . . . . . . 14

5.2 Methodology . . . . . . . . . . . . . . . . . . . . . . . 14

5.3 Discussion . . . . . . . . . . . . . . . . . . . . . . . . . 14

6 The Techinical Characterization of Cramp by Effie Photos-Jones . . . . . . . . . . . . . 16

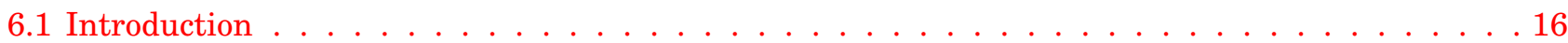

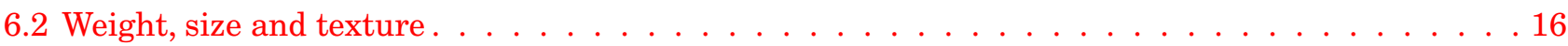

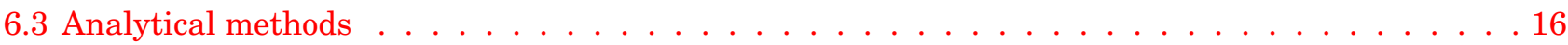

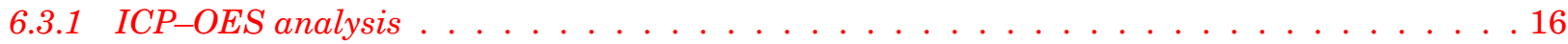

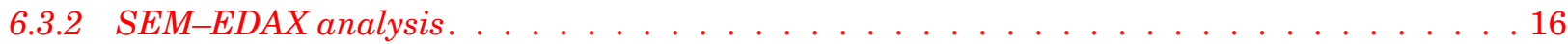

6.4 Results . . . . . . . . . . . . . . . . . . . . . . . . 16

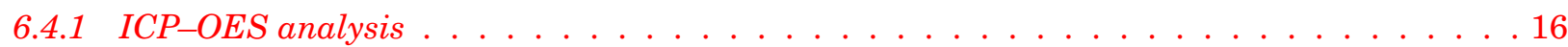

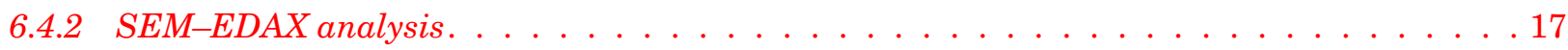

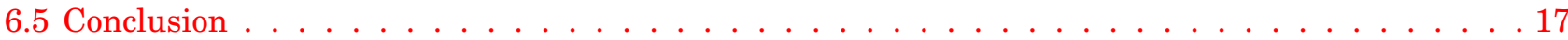


7 Comment on the Pottery by Ann MacSween . . . . . . . . . . . . . . . . . 18

8 Coarse Stone Report by Ann Clarke . . . . . . . . . . . . . . . . . . . . . 19

8.1 Description . . . . . . . . . . . . . . . . . . . . . . . 19

8.1 .1 Flaked stone bars. . . . . . . . . . . . . . . . . . . . . . . . . 19

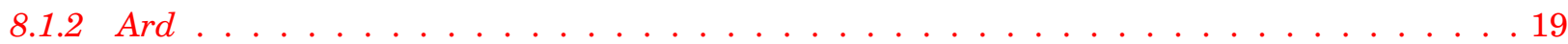

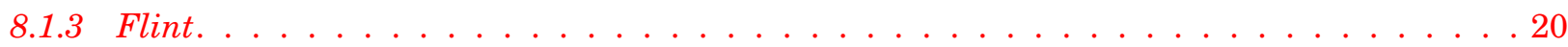

8.1 .4 Flaked flagstone . . . . . . . . . . . . . . . . . . . . . . 20

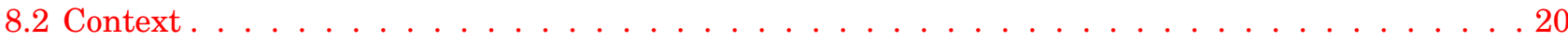

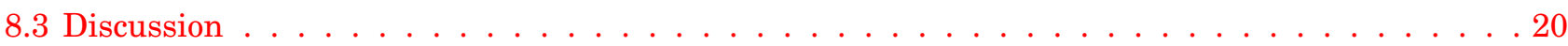

9 The Steatite Vessels by Paul M Sharman . . . . . . . . . . . . . . . . . . . . . .21

9.1 Introduction . . . . . . . . . . . . . . . . . . . . . . . 21

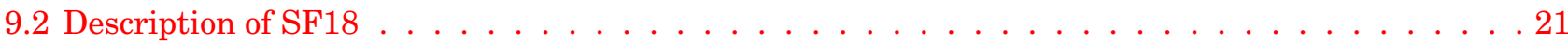

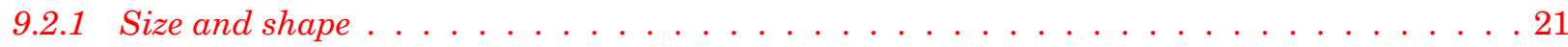

9.2 .2 Stone and condition . . . . . . . . . . . . . . . . . . . . . . 21

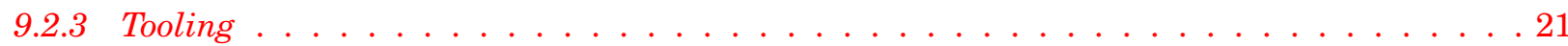

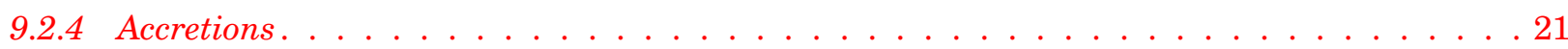

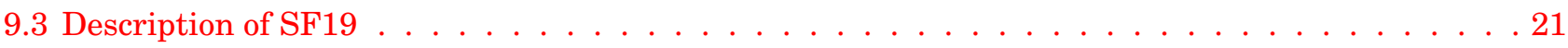

9.3 .1 Size and shape . . . . . . . . . . . . . . . . . . . . . 21

9.3 .2 Stone and condition . . . . . . . . . . . . . . . . . . . 21

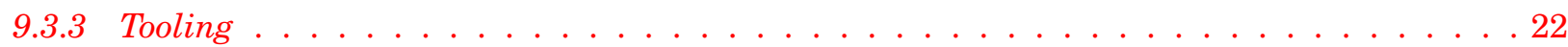

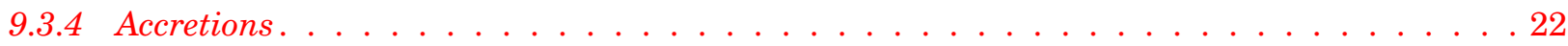

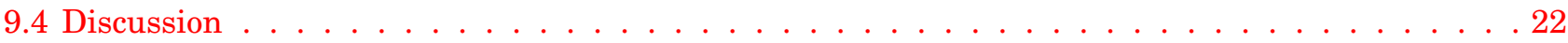

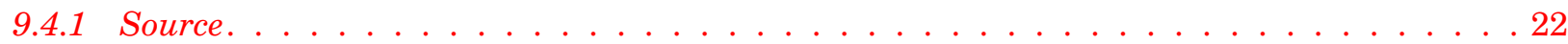

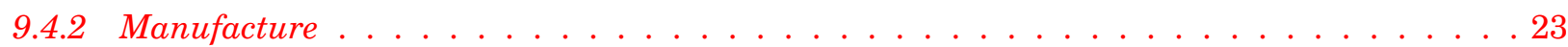

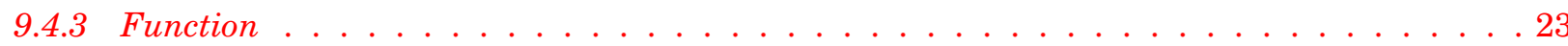

9.4.4 Form, parallels and dates . . . . . . . . . . . . . . . . 23

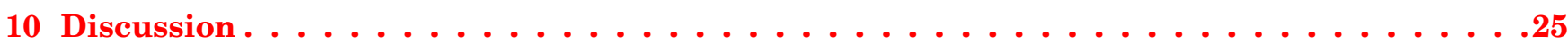

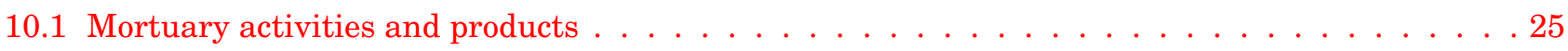

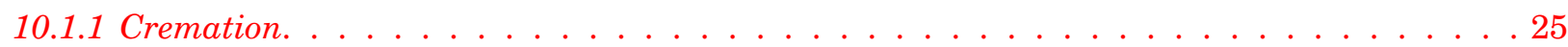

10.1 .2 Fuel. . . . . . . . . . . . . . . . . . . . . . . 25

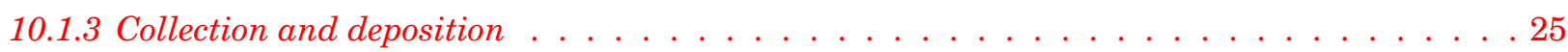

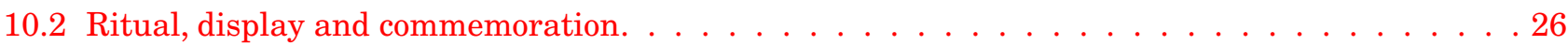

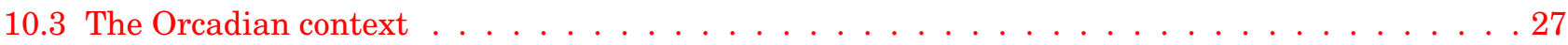

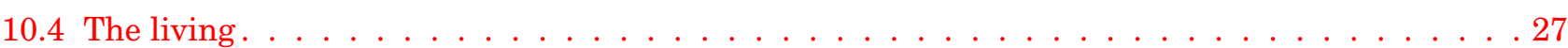

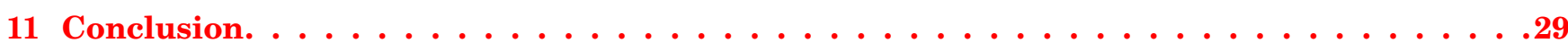

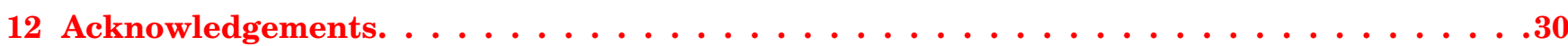

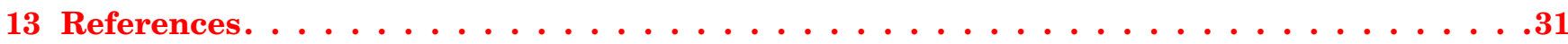




\section{List of illustrations}

Site location, based on Ordnance Survey maps (C) Crown copyright . . . . . . . . . . . . . . 2

2 Site location looking south, with Structure 1 in the foreground . . . . . . . . . . . . . . . .4

3 The primary phase of the site . . . . . . . . . . . . . . . . . . . . 5

4 Sections through fills and features . . . . . . . . . . . . . . . . . . . . . 6

5 Steatite vessel SF19 with lid SF20 in cist 069 . . . . . . . . . . . . . . . . . . .

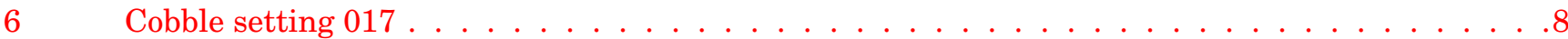

7 The freestanding kerb wall constructed over pits but respecting the cists . . . . . . . . . . . .9

8 The kerb infilled with rubble as part of the cairn construction . . . . . . . . . . . . 10

9 The coarse stone tools . . . . . . . . . . . . . . . . . . . . . . . 19

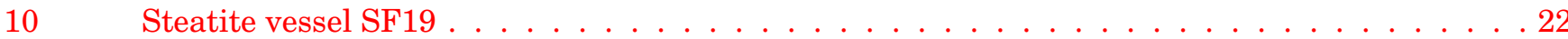

\section{List of tables}

1 Summary of number \& weight $(\mathrm{g})$ of ecofacts by feature. . . . . . . . . . . . . . . . .7

2 Radiocarbon determinations from wood charcoal samples submitted to the Scottish

Universities Environmental Research Centre AMS Facility. . . . . . . . . . . . . . . . . .7

3 Summary of bone weights, fragment sizes and percentage identified from each context. . . . . . 11

4 Identification of carbonized plant remains, in number of pieces and weight $\mathrm{g}$

(see illus 3 \& illus 4 for context locations) . . . . . . . . . . . . . . . . . . . . . . . . . 15 


\section{Summary}

Excavations in 1991 beside Loth Road, Sanday, revealed a funerary site, including two cists, which contained cremated human bone, and several pits. The cremation burial in one of the cists was contained in a soapstone vessel. These features presented evidence for the sorting, selection and differential deposition of pyre remains. The cists and pits were surmounted by a kerbed cairn of unusual construction. Radiocarbon dates from the pits placed the site in the Early to Middle Bronze Age. 


\section{Introduction}

\subsection{Location}

The site is located towards the south end of the Spurness peninsula, at the south-west end of Sanday, Orkney (NGR: HY 60553 34489) in Cross and Burness parish (illus 1 ). The spine of the ridge is formed of Rousay Flags, flanked by Eday Sandstone Beds, all of which belong to the Devonian of Middle Old Red Sandstone period (Mykura 1976, 82). The site lies in rough heath land in a prominent position at a height of $c 31 \mathrm{~m}$ OD.

\subsection{Discovery and survey}

The site was first recorded by Dr Raymond Lamb, then the Orkney County Archaeologist, as 'Two low shapeless mounds [which] may be burial mounds. OR369' (Lamb 1980, 24). In late 1990 and early 1991, Bradford University conducted an archaeological survey along the proposed access route to the new ferry terminal at Loth, near the south end of Spur Ness (Hunter \& Dockrill 1991). The survey divided the site into two - Site 19 to the east and Site 20 to the west-identifying both as probable burnt mounds, due to the location of burnt or midden material by geophysical survey, although the surveyors noted that there was still a possibility that they were Bronze Age burial cairns (Hunter \& Dockrill 1991, 7-8). A topographic survey of Site 19 shows two merging mounds (illus 1). The north mound (Structure 1) was sub-rectangular, some $11 \mathrm{~m}$ long NNE/SSW, $6 \mathrm{~m}$ wide and up to $0.6 \mathrm{~m}$ high. The south mound (Structure 2) was sub-circular, $5-7 \mathrm{~m}$ in diameter and roughly $1 \mathrm{~m}$ high (Hunter \& Dockrill 1991, 25, fig 6).

\subsection{Excavation}

Orkney Islands Council funded the excavation of Site 19 prior to the construction of the new road. The excavation was conducted in June and July 1991

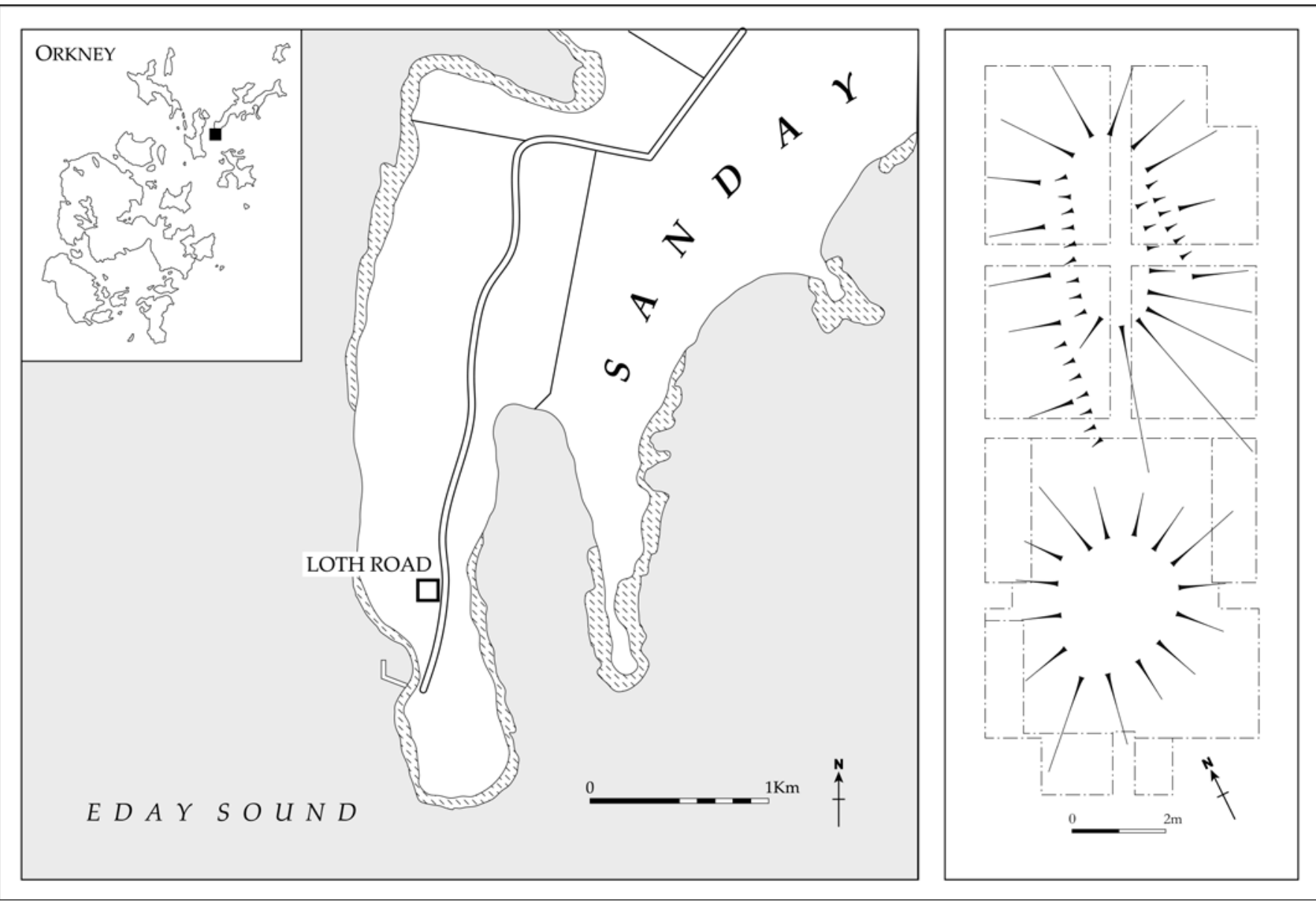

Illus 1 Site location, based on Ordnance Survey maps (C) Crown copyright 
over a period of two weeks by Ruth Gosney (now Peace) and Alan Braby. No provision for funding post-excavation analysis was in place, so the site records, finds and samples were held in storage by the Orkney Museum and Ruth Peace. Orkney Archaeological Trust was kindly funded by a grant from Historic Scotland to bring the site to publication. It should be noted that two of the plans and ten samples could not be located. The missing samples and the fact that not all contexts were sampled has affected the type and quantity of material retrieved from features across the site. 


\section{$3 \quad$ Excavation Results}

\subsection{Structure 1}

This comprised a sub-circular mound, $5-6 \mathrm{~m}$ in diameter, of collapsed and/or plough-disturbed rubble (illus 2) that underlay a possible turf horizon of silty loam (context 001), which also lay around Structure 2. The edge of the rubble mound overlay and was set into a layer of firm silty clay. Due to the spread and lack of structure of the rubble, the mound was interpreted as a clearance cairn and not excavated further. Over 100 pieces of vitrified fuel ash waste (cramp) were collected from the topsoil over Structure 1.

\subsection{Structure 2}

This comprised an irregular mound of gravel and rubble up to $0.35 \mathrm{~m}$ high and $4.6-5.4 \mathrm{~m}$ in diameter (illus 2). The top of a kerb and a cist were visible through this material. The kerb was a sub-circular wall infilled with rubble, which appeared to respect two cists and overlay six of a group of 13 infilled pits cut into the stony silt loam subsoil and the underlying C-horizon of firm pale yellow-brown clay (illus 7). The northern edge of the kerb cut the south side of one of three 'boxes', also set into the underlying natural surface (illus 3). (The term 'box' is used as a convenient descriptive word to denote the shape and small size of these rectangular stonelined features in comparison with the cists and is not meant to imply a function.) Two small spreads and a cobble setting, which overlay the subsoil, were the only other features noted (illus 7). The fills of cists and boxes were fully excavated, whereas the fills of cuts were half-sectioned. It is possible that the excavation area did not encompass all of the features belonging to the group. During the removal of the topsoil from the area of Structure 2, a flaked stone bar, three pieces of cramp and a few fragments of post-medieval agricultural ironmongery were retrieved.

\subsubsection{Pits}

The pits (illus $3 \& 4$ ) were all sub-circular to suboval, with diameters between 0.30 and $1.00 \mathrm{~m}$. Only two cuts (contexts 058 and 064) had diameters under $0.50 \mathrm{~m}$. The pits were $100-250 \mathrm{~mm}$ deep, with sides that varied from steep to gentle. Four of the pits $(040,042,058 \& 064)$ were distinctly concave, whilst the others had uneven or flattish bases. One of the largest pits (context 068) had some small upright stones set around its upper edge. None of the separate characteristics appeared to form

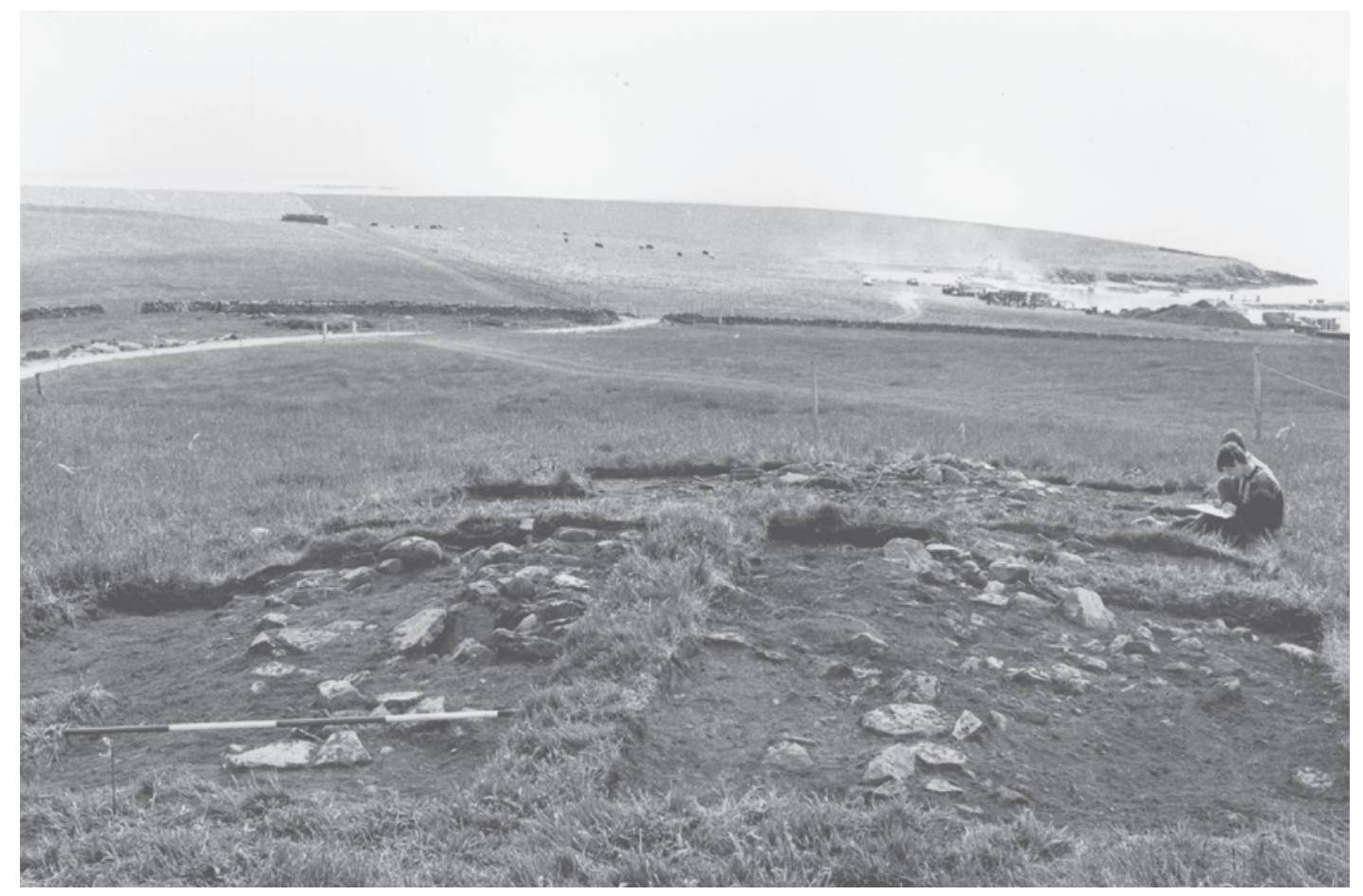

Illus 2 Site location looking south, with Structure 1 in the foreground 


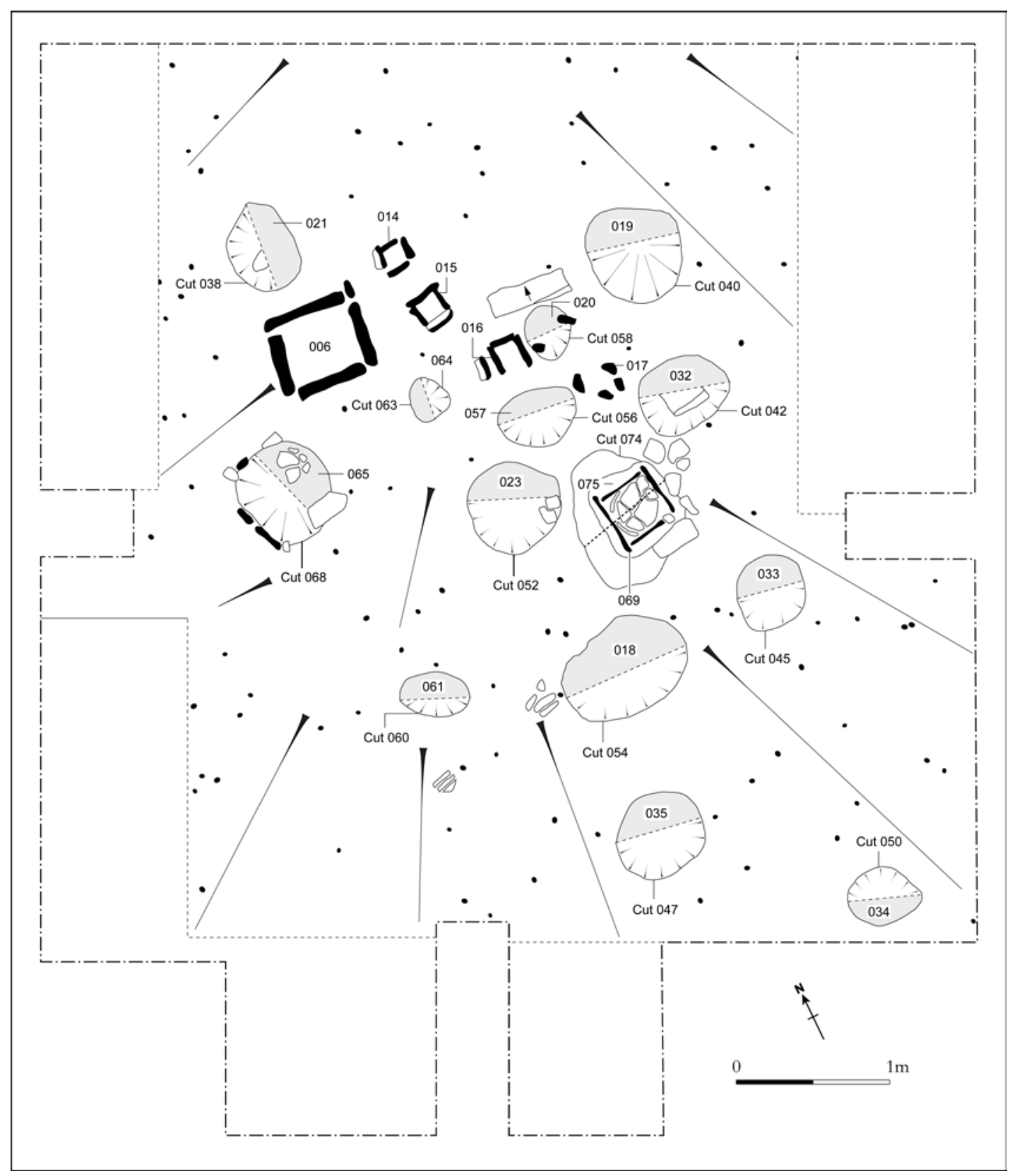

Illus 3 The primary phase of the site

significant groups. It is likely that the pits were filled shortly after they were dug, because there was no degradation of the cut edges and no silt had accumulated in the bottom of the pits by natural weathering processes.

The fills of the cuts comprised up to three types primary, 'secondary'and capping. Most of the samples processed were from the primary fills, which bore no similarity to the layers through which the pits were dug. They consisted of pyre-derived material - dark ashy and occasionally peaty soils, containing fuel remains such as burnt peat, carbonized heather from heathy turves and wood charcoal from scrub alder, hazel and birch (Table 1). Carbonized wild fuel resources dominate the fills, except context 055 in Pit 054, which was rich in wood charcoal fragments, one of which provided a probable radiocarbon date of $1520-1320$ cal BC (Table 2). The material was gathered quickly, because there was no degradation of the charcoal in any of these fills, except for some iron panning deposits caused by groundwater penetration post burial.

Some of the primary fills contained additional or different material (Table 1). As well as fuel debris, Fill 046 in Pit 045 contained 30 fragments of cremated bone and five pieces of cramp. Three sherds of pottery were found in Fill 051 in Pit 050 along with the fuel debris, which provided a probable radiocarbon date of 1520-1310 cal BC (Table 2). Fuel debris from Fill 043 in Pit 042, which also contained a large rectangular block of stone, provided probable radiocarbon dates of 1610-1400 and 1680-1430 cal 


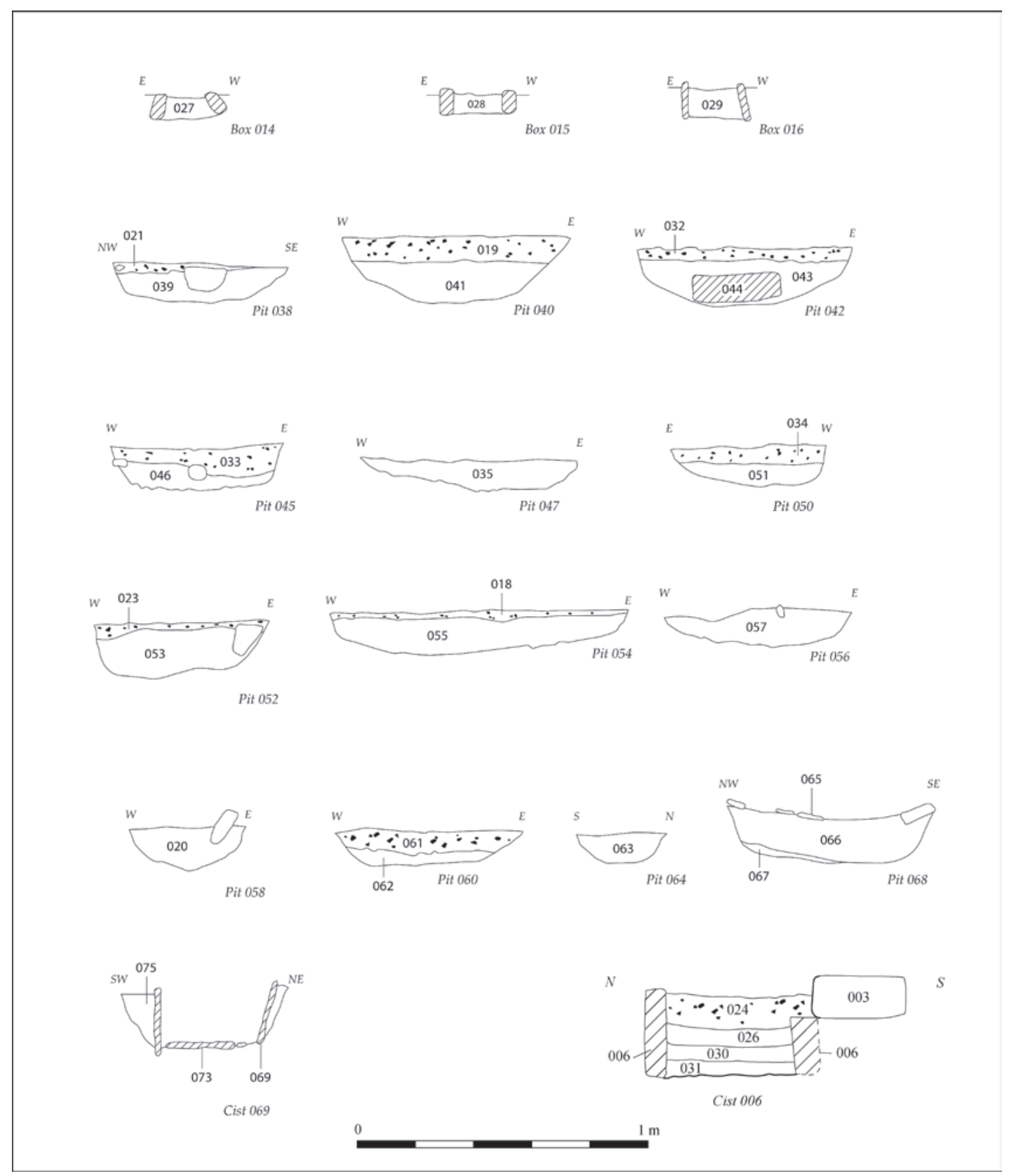

Illus 4 Sections through fills and features

BC (Table 2). Fill 053 in Pit 052 contained virtually no fuel debris, but 13 pieces of cramp. Only four pieces of cramp in total were found in the rest of the primary fills. Steatite vessel sherds SF18 were found in Fill 066 in Pit 068. The sample from this deposit was not found. None of the pits cuts another, indicating that they belong to a single phase. The dates obtained overlap closely, indicating that the features not sealed by the structure were statistically no later than those that were. Therefore, it is likely that they are contemporary. The dates place the site firmly in the earlier Bronze Age, spanning the later part of the Early Bronze Age and the earlier part of the Middle Bronze Age.

The dates have been calibrated using the University of Oxford Radiocarbon Accelerator Unit calibration program, OxCal3 (Bronk Ramsey 2001), with atmospheric data from Stuiver et al 1998.

The second type of deposit, usually the secondary fill in a pit, occasionally the only fill, was a diluted version of the pyre-derived primary fills, mixed with a small amount of gravel, presumably from the ground surface at the point of collection or deposition. No samples remained from these deposits, but 10 cremated bone fragments from context 018 in Pit 054 and three cremated bone fragments from context 023 in Pit 052 were retrieved as finds SF22 and SF23, respectively.

The third type of fill sealed the top of four pits (040, 060, 058 \& 068) and comprised gravelly capping material partly derived from the surrounding subsoil, perhaps from some of the material dug out when the pits were cut. 
Table 1 Summary of number \& weight $(g)$ of ecofacts by feature

\begin{tabular}{|c|c|c|c|c|c|c|c|c|}
\hline Feature & Bone (no) & $\begin{array}{c}\text { Wild } \\
\text { resources }\end{array}$ & $\begin{array}{l}\text { Wood } \\
\text { charcoal }\end{array}$ & Cramp & $\begin{array}{c}\text { Bone } \\
\text { (weight, } \mathbf{g})\end{array}$ & $\begin{array}{c}\text { Wild } \\
\text { resources }\end{array}$ & $\begin{array}{l}\text { Wood } \\
\text { charcoal }\end{array}$ & Cramp \\
\hline Pit 038 & 0 & 129 & 0 & 0 & 0 & 7.34 & 0 & 0 \\
\hline Pit 042 & 0 & 191 & 16 & 0 & 0 & 10.27 & 3.00 & 0 \\
\hline Pit 045 & 30 & 130 & 0 & 5 & 1.4 & 21.83 & 0 & 0.8 \\
\hline Pit 047 & 0 & 87 & 1 & 1 & 0 & 1.73 & 0.08 & 2.3 \\
\hline Pit 050 & 0 & 170 & 4 & 0 & 0 & 10.93 & 3.05 & 0 \\
\hline Pit 052 & 3 & 7 & 0 & 13 & 1.1 & 0.01 & 0 & 1.4 \\
\hline Pit 054 & 10 & 118 & 25 & 1 & 1.6 & 0.01 & 34.54 & 0.6 \\
\hline Pit 060 & 0 & 52 & 0 & 30 & 0 & 3.14 & 0 & 10.2 \\
\hline Box 014 & 0 & 3 & 14 & 16 & 0 & 0.05 & 1.68 & 4.6 \\
\hline Box 016 & 0 & 5 & 2 & 7 & 0 & 0.05 & 0.15 & 1.5 \\
\hline Cist 006 & 84 & 4 & 0 & 328 & 5.1 & 0.14 & 0 & 356.0 \\
\hline Cist 069 & 89 & 2 & 0 & 25 & 4.6 & 0.28 & 0 & 3.1 \\
\hline Total pits & 43 & 884 & 46 & 50 & 4.1 & 55.25 & 40.67 & 14.7 \\
\hline Total boxes & 0 & 8 & 16 & 23 & & 0.10 & 1.83 & 6.1 \\
\hline Total cists & 173 & 6 & 0 & 353 & 9.7 & 0.42 & 0 & 359.1 \\
\hline
\end{tabular}

Table 2 Radiocarbon determinations from wood charcoal samples submitted to the Scottish Universities Environmental Research Centre AMS Facility

\begin{tabular}{|c|c|c|c|c|c|}
\hline Lab code & Species & Context & Age BP & $\delta^{13} \mathbf{C}$ & $\begin{array}{l}\text { Calibrated date range } \\
(95.4 \% \text { probability })\end{array}$ \\
\hline $\begin{array}{l}\text { SUERC-3746 } \\
(\mathrm{GU}-12290)\end{array}$ & Larix / Picea & $\begin{array}{l}\text { 029: fill of stone box; } 016 \text { : } \\
\text { sealed by structure and } \\
\text { capping }(002)\end{array}$ & $3500 \pm 45$ & -23.7 & $\begin{array}{l}1720 \mathrm{BC}(5.2 \%) \text { to } 1680 \mathrm{BC} \\
1940 \mathrm{BC}(90.2 \%) \text { to } 1730 \mathrm{BC}\end{array}$ \\
\hline $\begin{array}{l}\text { SUERC-3759 } \\
(\text { GU-12293) }\end{array}$ & Betula & 043: primary fill of Pit 042 & $3210 \pm 40$ & -25.7 & $\begin{array}{l}1610 \mathrm{BC}(5.3 \%) \text { to } 1560 \text { вС } 1530 \\
\mathrm{BC}(90.1 \%) \text { to } 1400 \mathrm{BC}\end{array}$ \\
\hline $\begin{array}{l}\text { SUERC-3760 } \\
\text { (GU-12294) }\end{array}$ & Corylus & 043: primary fill of Pit 042 & $3265 \pm 35$ & -25.7 & $\begin{array}{l}1680 \mathrm{BC}(1.7 \%) \text { to } 1670 \mathrm{BC} 1630 \\
\mathrm{BC}(93.7 \%) \text { to } 1430 \mathrm{BC}\end{array}$ \\
\hline $\begin{array}{l}\text { SUERC-3747 } \\
(\text { GU-12291) }\end{array}$ & Betula & 051: primary fill of Pit 050 & $3135 \pm 40$ & -25.6 & $1520 \mathrm{вс}(95.4 \%)$ to $1310 \mathrm{BC}$ \\
\hline $\begin{array}{l}\text { SUERC-3748 } \\
(\mathrm{GU}-12292)\end{array}$ & Corylus & $\begin{array}{l}\text { 055: primary fill of Pit } 054 \text {, } \\
\text { sealed by structure }\end{array}$ & $3160 \pm 35$ & -26.7 & $\begin{array}{l}1340 \mathrm{BC}(4.5 \%) \text { to } 1320 \mathrm{BC} \\
1520 \mathrm{BC}(93.7 \%) \text { to } 1380 \mathrm{BC}\end{array}$ \\
\hline
\end{tabular}

Some of the pits may have been truncated, but the fact that the structure sealed pits with single fills as well as pits with capping deposits and that pits with capping material lay in close proximity to pits with single fills outwith the area of the structure indicates that most pits and fills were not disturbed.

\subsection{2 'Boxes'}

These three features were set into the ground in close proximity in the northern part of the site (illus $3 \& 4$ ). Internally, the boxes were roughly $150-220 \mathrm{~mm}$ square and $100-140 \mathrm{~mm}$ deep. The sides were flag orthostats, whilst the bases were formed by the surface of the underlying C-horizon clay (context 037). The south side of box (context 016) was slightly displaced and overlain by the stone kerb. The boxes were filled with single pyre-derived ashy deposits that contained small amounts of fuel debris and cramp, but no bone (Table 1). It is difficult to interpret these features, except that the fact they contain at least some pyre material may indicate that they are containers rather than, for example, post settings. A fragment of driftwood from Fill 029 in Box 016 produced a probable radiocarbon date of 1940-1680 cal BC (Table 2). The date is that of the tree's fall in the Americas, not the fragment's deposition in Orkney, and therefore can only provide a terminus post quem for the kerb and, probably, the whole site. 


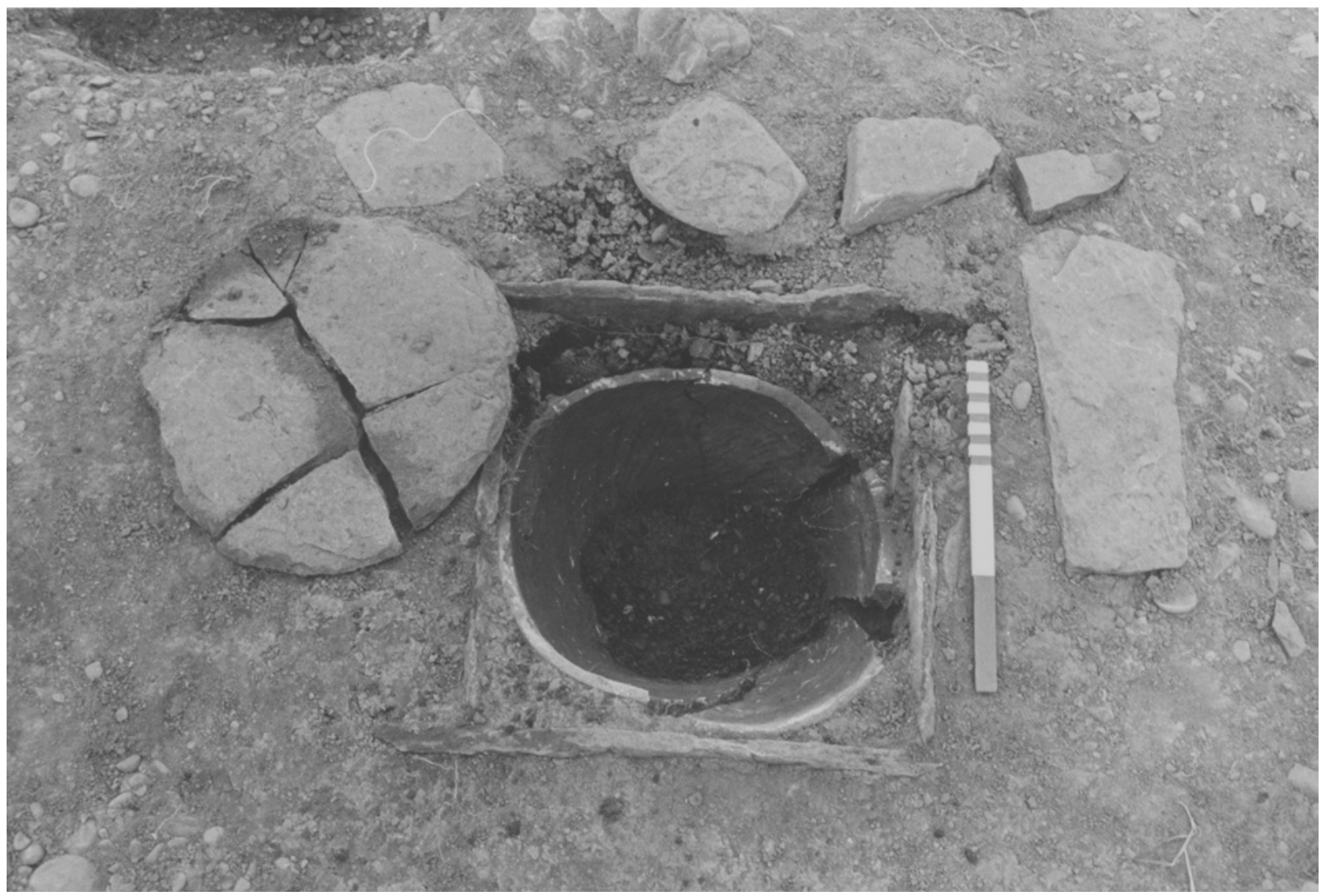

Illus 5 Steatite vessel SF19 with lid SF20 in cist 069

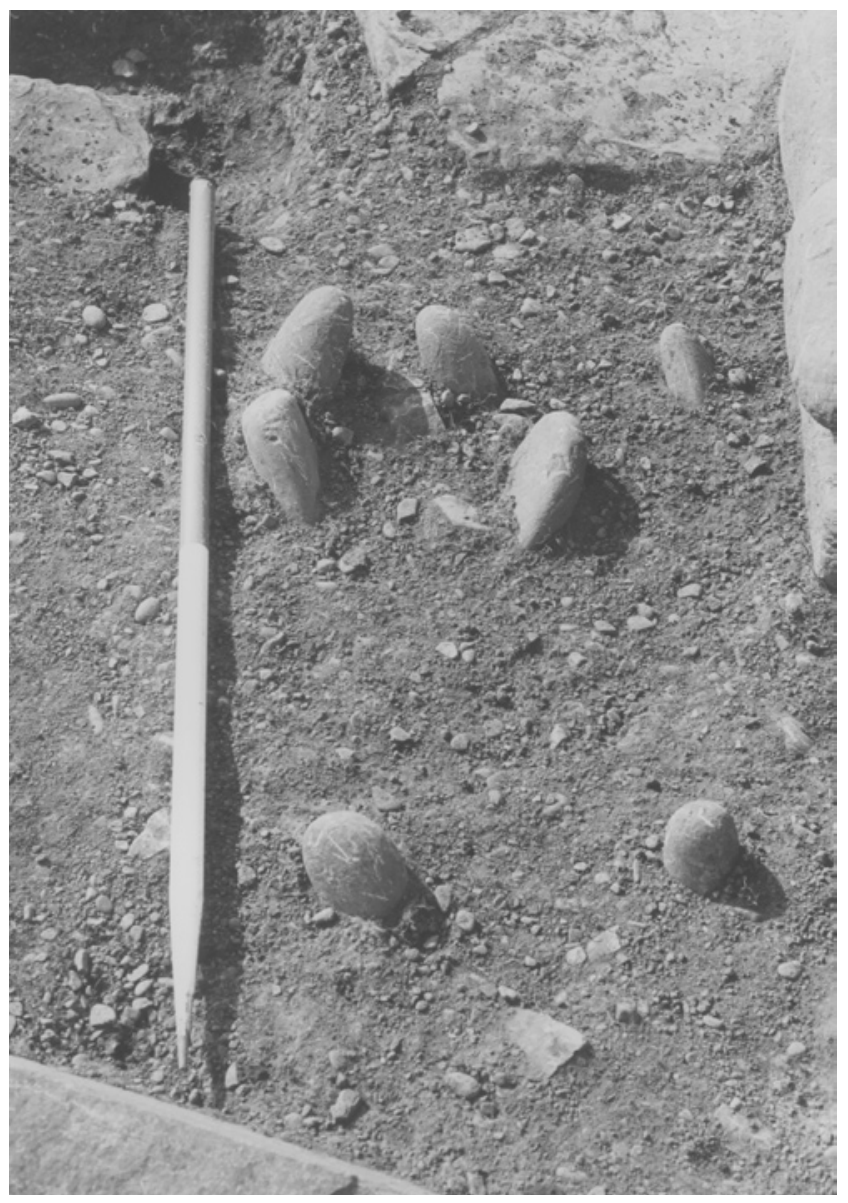

Illus 6 Cobble setting 017

\subsubsection{Cists}

Rectangular Cist 006 lay to the west of the boxes at the north edge of the kerb wall (illus $3 \& 7$ ). It measured $460 \mathrm{~mm}$ north/south by $560 \mathrm{~mm}$ east/west and was $300 \mathrm{~mm}$ deep. The sides were flag orthostats, whilst the base was formed by the surface of the C-horizon clay. The orthostat forming the south side of the cist was slightly lower than the other sides and was built on by the outer face of the kerb (illus 4). The other three sides of the cist stood proud of the surrounding surface, at the same level as the surviving top of the kerb.

The cist contained three black ashy pyre-derived fills. A few pieces of cramp were retrieved from the primary and upper fills as SF25 and SF13, but a sample survived to be processed from the secondary fill (context 030), showing it to be a formal burial. It contained over 300 pieces of cramp and 84 fragments of cremated bone, with only four lumps of burnt peat (Table 1). The fills were sealed after the construction of the kerb wall by gravelly material similar to that capping some of the pits.

Cist 069 lay to the south of the boxes at the east side of the kerb, set flush with the ground surface in a $650 \mathrm{~mm}$ square, $250 \mathrm{~mm}$ deep flat-bottomed cut (illus 3 \& 4). Internally, the cist was $400 \mathrm{~mm}$ square and $200 \mathrm{~mm}$ deep, with flag orthostat sides. After these were set in place, the cut was backfilled against them and broken flag fragments, two of which were shaped, and were inserted to form the base of the cist. 


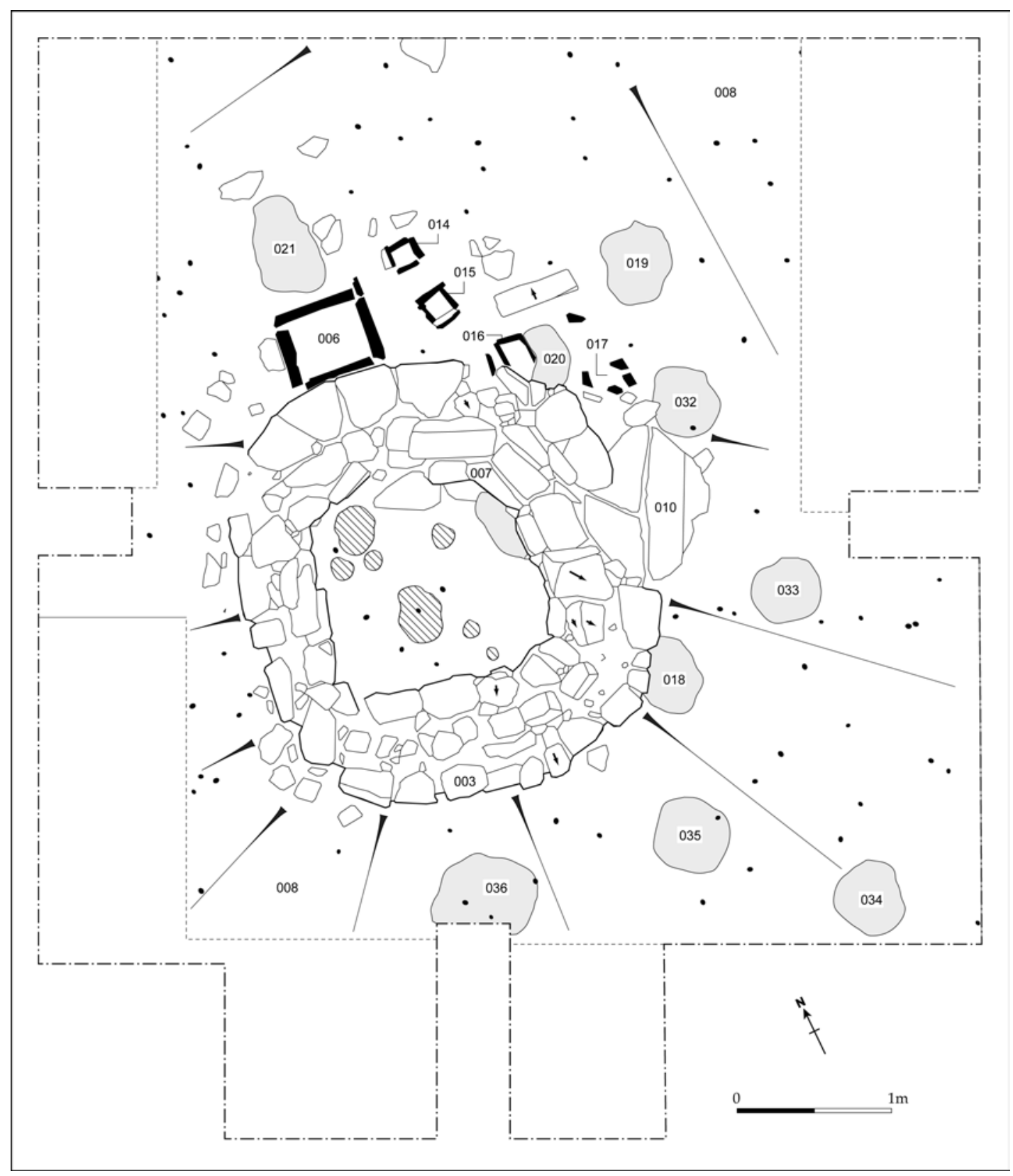

Illus 7 The freestanding kerb wall constructed over pits but respecting the cists

A lozenge-shaped flagstone (context 010) capped the whole feature, overlapped but essentially respected by the outer face of the kerb wall (illus 7).

Steatite vessel SF19 was placed upright into the cist, fitting it snugly and sealed with a shaped circular stone lid, SF20 (illus 5), which had broken and become slightly displaced after burial. The primary fill of the urn comprised a burial of black ashy pyre-derived soil and 82 cremated bone fragments, probably from an infant, with 11 pieces of cramp (Table 1). The upper fill of the urn and the backfill around the urn in the cist included loose ashy soil, several pieces of cramp and a few fragments of cremated adult bone. However, the excavators noted that these deposits might have been the result of/or contaminated by soil percolation, after the flags and lid sealing the cist and urn had cracked. This observation was confirmed by the XRF analysis of a metal flake from the upper fill of the urn. The analysis, conducted by Dr Jim Tate, National Museums of Scotland, showed a modern mixture of iron with a little titanium.

\subsubsection{Spreads and cobble setting}

North of Cist 069, on the south-east side of Box 016 , was a horseshoe-shaped setting, some 160 by $200 \mathrm{~mm}$, made of four rounded cobbles set on end (illus 3 \& 6). Two similar cobbles lay $300 \mathrm{~mm}$ to the north in the top of Fill 020 in Pit 058. It is not certain whether these cobbles are part of the setting, or have been displaced from it and included in the fill. The site photographs suggest that the stones may have been cobble tools. 


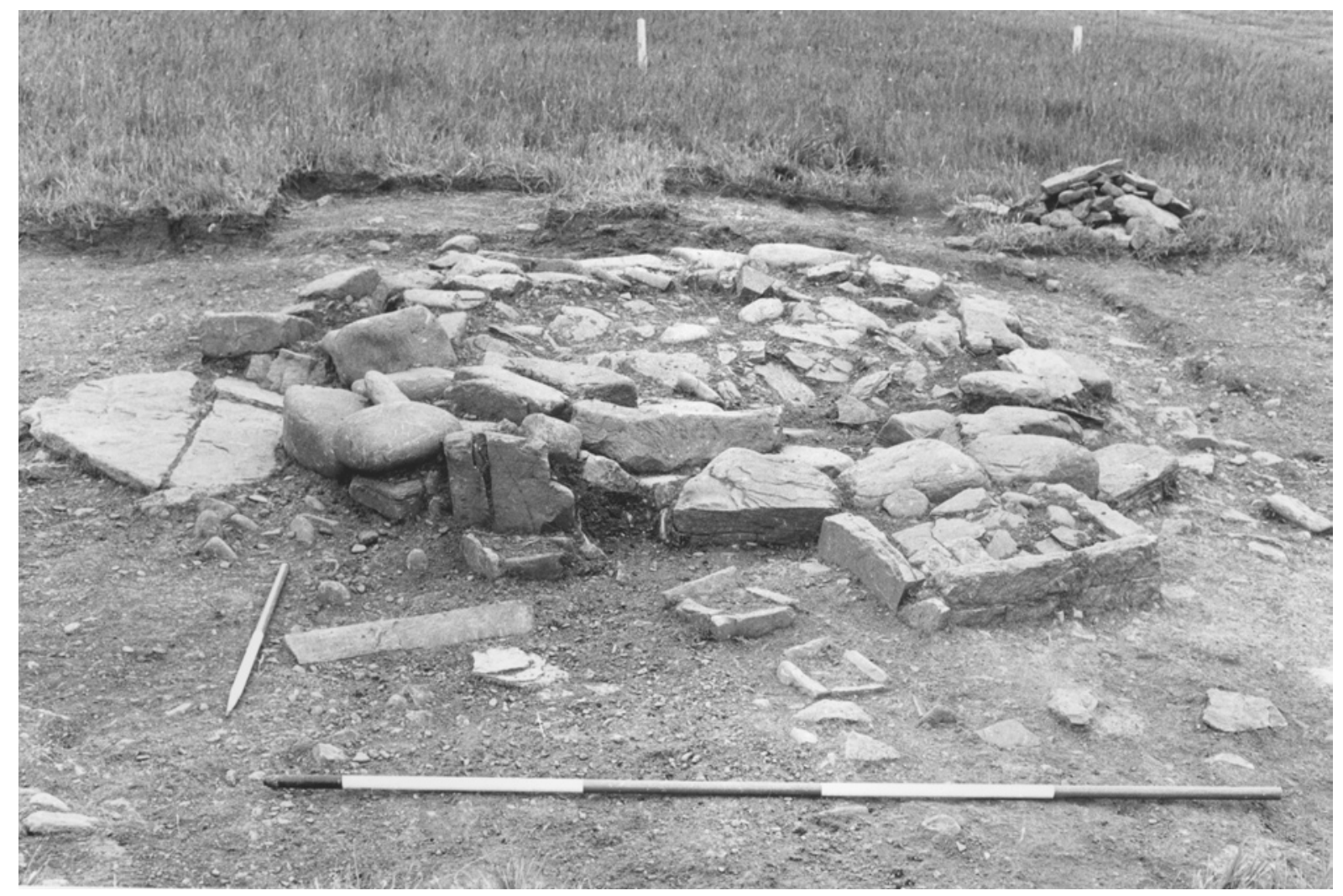

Illus 8 The kerb infilled with rubble as part of the cairn construction

There were two patches of ashy material, one (context 036) at the south-west edge of the site (illus 7) and the other (context 059) south-west of Box 016. The latter contained five sherds of pottery, SF17. There is no record of the ground below them being heat-affected, so it is more likely that these are deposits than the remains of fires in situ.

\subsubsection{The kerb}

A freestanding sub-circular stone kerb was then built on the site, with an internal diameter of $1.5-1.9 \mathrm{~m}$ and walls $0.5-0.9 \mathrm{~m}$ thick, standing to a maximum height of $0.26 \mathrm{~m}$ (illus 7). It was built of an uncoursed mixture of stone, from rounded boulders to angular flags and blocks of variable sizes up to 400 by 400 by $250 \mathrm{~mm}$. The masonry was up to three stones high, faced internally and externally and had a rubble and soil core. A patchy compacted surface (context 048) was noted inside the structure, perhaps the result of construction activity. The kerb appeared to be placed randomly over the filled pits, cut the south-west corner of Box 016 and overlapped but respected both of the cists.

\subsubsection{The cairn}

The kerb was infilled with at least two deposits of gravel, flags and rubble (illus 8). A spread of similar material (context 009) to the north and east of the structure may be related to this activity and it is possible that Cist 006 was capped with context 024 at this time. A gravelly layer of rounded pebbles (context 002) was piled over the infilled kerb to form a cairn or mound. A flint and four flaked stone bars or mattocks were included in this capping material, which may have been brought to the site, because the angular stones in the subsoil were not similar. Clearly, the material had collapsed and spread out from its original form up to $1.6 \mathrm{~m}$ beyond the outer face of the kerb. A degree of later disturbance is indicated by the displacement of at least one of the stones from the kerb wall.

A possible turf horizon of humic loam (context 001) that contained a broken ard point, SF10, extended across the rest of the area not covered by the collapsed cairn material. It is recorded that the cairn material overlapped (context 001), but there is no record of the full extent or relationships of this layer, which also overlay Structure 1. Therefore, context 001 could be part of the topsoil horizon, with a small overlap from the cairn material resulting from soil creep (there is no sign of ploughing at the site), or context 001 could be a buried prehistoric topsoil horizon. The latter interpretation has the corollary that Structure 1 must be a prehistoric cairn, whether burial or clearance. 


\section{The Cremated Human Remains by Julie A Roberts}

\subsection{Introduction}

The preservation of the remains was very poor. A total number of 216 fragments of bone with a combined weight of just $13.8 \mathrm{~g}$ were examined (Table 3 ). The majority of fragments measured less than $10 \mathrm{~mm}$ in diameter, and the largest fragment size was $20.1 \mathrm{~mm}$. There was extensive erosion of the surface of the bones, and a relatively large percentage of the fragments, particularly those derived from the samples, could not be identified to skeletal element or region of the body. Fragments were termed unidentified if they could not be ascribed to a specific element or body area.

The aims of analysis, where preservation allowed, were to: (a) identify the species of the burnt bone; (b) determine the minimum number of individuals present within each context, and across the site as a whole; (c) estimate age at death and sex; (d) record any skeletal pathology or variants; (e) provide information relating to mortuary practice.

\subsection{Results}

\subsubsection{Species and minimum number of individuals (MNI) present}

No cremated animal bone was identified, although the criteria used for distinguishing species (morphology, surface texture and density) were hard to apply, due to the poor preservation of the material.

The calculation of the minimum number of individuals present (MNI) was based on the presence of repeated skeletal elements, or elements belonging to individuals of clearly different biological age. If each context is regarded as having contained at least one separate individual, then a minimum number of seven individuals from across the site could be recorded. There were, however, no repeated skeletal elements amongst the assemblage as a whole, although individuals of different biological age were identified. It is possible given the complexities of Bronze Age mortuary rituals that single individuals could have been divided between different burial places. Based on these criteria, if all the bone recovered from the site is regarded as a single assemblage, then a minimum number of only two individuals could be recorded.

\subsubsection{Age at death and sex}

Age at death and sex were considered with reference to standards outlined previously (Buikstra \& Ubelaker 1994), but for the most part the fragments were too small and eroded to enable an accurate conclusion to be reached. No sexually dimorphic skeletal elements were preserved so it was not possible to determine the sex of any of the individuals.

None of the fragments in S25, from context 071 (the primary fill of the steatite urn), could be identified to skeletal element, but some could be identified as long bone. The cortical thickness and diameter of some of the larger fragments suggested that this was an immature individual, whilst the periosteal surface of the fragments indicated that the remains were probably those of an infant rather than an older child.

All the other bone examined from the site was probably adult. The remains from S24 and S26, from the upper fill of the urn and the fill of the cist respectively, could be identified only as probable adult because they comprised just a few fragments of eroded cortical bone, each measuring less than $5 \mathrm{~mm}$. The bone from SF22 and SF23, and S8 and

Table 3 Summary of bone weights, fragment sizes and percentage identified from each context

\begin{tabular}{|c|c|c|c|c|c|c|c|}
\hline $\begin{array}{l}\text { Small find/ } \\
\text { sample }\end{array}$ & Context & Context type & $\begin{array}{l}\text { Weight } \\
\text { (g) }\end{array}$ & $\begin{array}{c}\text { No of } \\
\text { Fragments }\end{array}$ & $\begin{array}{l}\text { Fragment } \\
\text { size }(\mathbf{m m})\end{array}$ & $\begin{array}{c}\% \\
\text { Identified }\end{array}$ & $\begin{array}{c}\% \\
\text { Unidentified }\end{array}$ \\
\hline SF22 & 018 & Secondary fill, Pit 054 & 1.6 & 10 & $3.4-13.7$ & 87 & 13 \\
\hline SF23 & 023 & Secondary fill, Pit 052 & 1.1 & 3 & $13.8-15.5$ & 100 & 0 \\
\hline S8 & 030 & Secondary fill, Cist 006 & 5.1 & 84 & $3.3-20.1$ & 63 & 37 \\
\hline S11 & 046 & Primary fill, Pit 045 & 1.4 & 30 & $3.4-15.5$ & 29 & 71 \\
\hline $\mathrm{S} 24$ & 070 & $\begin{array}{l}\text { Secondary (top) fill of } \\
\text { steatite vessel SF19, Cist } \\
069\end{array}$ & 0.1 & 2 & $4.2-4.4$ & 0 & 100 \\
\hline $\mathrm{S} 25$ & 071 & $\begin{array}{l}\text { Primary fill of steatite } \\
\text { vessel SF19, Cist } 069\end{array}$ & 4.3 & 82 & $3.6-11.3$ & 0 & 100 \\
\hline S26 & 072 & Contents of Cist 069 & 0.2 & 5 & $4.3-6.9$ & 0 & 100 \\
\hline
\end{tabular}


S11 was identified as adult primarily on the basis of the cortical thickness of the long bones, the thickness of the cranial fragments, and the presence of adult dentition and tooth sockets. A more precise age range for the adult remains could not be given.

\subsubsection{Pathology and non-metric traits}

Certain types of skeletal pathology can survive the cremation process (Reinhard \& Fink 1994; McSweeney 1995; Roberts 1998). Non-metric traits, skeletal variants that are generally used to compare differences between population groups, are also frequently observed in cremated bone (Roberts 1998; Roberts 2000). No pathological conditions or nonmetric traits were observed in the remains from Loth Road. This was almost certainly due to the poor state of preservation of the remains.

\subsubsection{Mortuary practice}

The colour, fracture patterns and surface texture of all the bone fragments from Loth Road were observed and recorded. The predominant colour of the fragments from all contexts was white, indicating that the bodies had been cremated at temperatures in excess of $700-800^{\circ} \mathrm{C}$ for a sustained period of time (Shipman et al 1984; Holck 1986; Holden et al 1995). The exceptions to this were a small number of long bone fragments, which were light grey on the endosteal surface, and a number of fragments of trabecular bone, which were also light grey. This indicated that the inner surfaces of these particular bones had not quite reached the same high temperatures as the outside. No further inferences could be made about this, however, because the fragments could not be identified to element. There was no evidence of differential combustion of the skeleton that might suggest a particular body position on the pyre, but so little of it was surviving in each burial that any patterns could easily have been missed. The predominant colour of the remains was consistent with the findings from many of the Orcadian cremations (McKinley 1996; McKinley 1997; Roberts 2000), which indicate a sophisticated level of technology amongst the Bronze Age population, both in terms of pyre construction and an understanding of the whole cremation process.

Burning dry bones causes longitudinal splitting but no warping or twisting, whilst burning fleshcovered bones produces curved transverse fracture lines, irregular longitudinal splitting and marked warping (Ubelaker 1989; Buikstra \& Ubelaker 1994). The majority of the fragments were too small or eroded to be assessed for patterns of cracking. The exceptions to this were a fragment of radius showing evidence of curved cracking (from S8), and a fragment of long bone with transverse checking (from SF22). This evidence suggests that at least these particular bodies had been cremated soon after death, while still fleshed (Ubelaker 1989) and not left exposed, or buried until only the bones remained as is still the practice in some parts of modern day Bali (Metcalf \& Huntington 1991, 143-7).

The average weights of a complete cremated modern male and female are $2283.5 \mathrm{~g}$ and $1615.7 \mathrm{~g}$, respectively (McKinley 1993). Clearly, the cremation burials from Loth Road represented only minute fractions of the original skeletons, ranging in weight from just $0.1 \mathrm{~g}$ to $5.1 \mathrm{~g}$. All the bone from the site added together total $13.8 \mathrm{~g}$, less than $0.3 \%$ of the expected total body weight of a female. This lack of complete individuals is a common phenomenon in Bronze Age cremation burials (McKinley 1997; Roberts 1998) and there are many possible interpretations for it, which depend on both intrinsic and extrinsic factors. The incomplete deposits could be seen as deliberate 'token' burials, the product of partial disintegration of the bone in the ground, or a combination of both. In deciding which might be the case, factors such as bone fragment size and the amount of surface erosion present are useful. Deposits that are badly fragmented and eroded are perhaps more likely to contain incomplete individuals because of taphonomic factors such as wind, rain and disturbance, whereas those with large fragment sizes and little surface erosion from funerary urns and cists are more likely to contain incomplete individuals because of selective burial practices (that is not to say, however, that the poorly preserved deposits did not also contain only a token burial to start with). If selective burial practices or deliberate incomplete recovery of bones from the pyre are thought to be the explanation for the absence of complete individuals then this raises a number of interesting questions about what constituted a sufficient amount of bone for burial from each person, what governed the choice of specific skeletal elements and whether the selection process varied according to the status, age or sex of the deceased.

In terms of the skeletal elements represented at Loth Road, there was a predominance of long bone or cortical bone with the axial skeleton being grossly under-represented. Fragments of cranium and tooth were identified in four of the better-preserved samples, SF23 and SF24, and S8 and S11. No fragments of vertebra, rib or pelvis were identified. These elements (particularly the vertebrae) have a high ratio of trabecular to cortical bone, which makes them more susceptible to damage from taphonomic agents than other bones with a greater proportion of cortical bone. The absence of these fragments from the burials at Loth Road might be an indication that physical and chemical agents played a major role in the differential preservation of the remains.

All of the contexts appeared to contain just a single individual, or parts of one. However, in steatite vessel SF19, the remains from the primary fill belonged to an infant, whilst those few fragments from the upper fill were thought to be a possible adult. This could constitute either a double burial that occurred simultaneously, or a primary and secondary burial 
within the same vessel, but the upper fill is highly contaminated. Double or multiple burials do occur with regularity in Bronze Age mortuary sites. At Linga Fiold, Sandwick, the frequency rate of multiple burials was recorded as being between 17 and 25\% (McKinley 1996). At Fordhouse Barrow in Coupar Angus, $75 \%$ of all multiple burials contained at least one immature individual (Roberts 1998). 


\section{Identification and Analysis of Carbonized Plant Remains by Diane Alldritt}

\subsection{Introduction}

Material from 14 samples was received for sorting, identification of botanical remains and analysis. Two bags (samples $16 \& 17$ ) of charcoal-rich sediment taken from context 055 were also received for the identification of sufficient short-lived charcoal types for radiocarbon dating.

\subsection{Methodology}

The samples were processed and analysed using standard techniques and equipment. Plant material was identified by comparison with modern material and reference texts (Beijerinck 1947; Schoch et al 1988). Plant nomenclature used in the text follows New Flora of the British Isles (Stace 1997). Charcoal fragments were identified using Anatomy of European Woods (Schweingruber 1990) and The Structure of Wood (Jane 1970). In the case of sample 16/17 from context 055, which produced a large quantity of charcoal, only a representative sample of 25 pieces was identified, in order to provide material for dating and to establish the range of charcoal types present. The results of the analysis are shown in Table 4.

\subsection{Discussion}

The analysis of the material produced no evidence for domestic activities, such as cereal processing, for the use of plant material as votive offerings or for feasting. Pit contexts contained the highest concentration of burnt peat and heather (Calluna) fragments, whilst cist contexts contained the highest concentration of cremated bone fragments, with very few carbonized plant remains.

The main fuel resource used at the site was peat, with possibly some use of drier heath (indicated by heather stems) or wet fen also suggested by the plant macrofossils (in particular, carbonized rhizome fragments). Identification of charcoal species has revealed the presence of birch (Betula), hazel (Corylus) and alder (Alnus), probably growing locally in sheltered areas as low-lying scrub on Sanday, which was used in the construction of funeral pyres, supplementing peat as fuel. The use of driftwood for fuel and construction was indicated by findings of Coniferous wood, in particular larch/spruce (Larix/Picea), which are not native species and most likely arrived in Orkney on currents from America (Dickson 1992). Driftwood collected from the shore would have provided a useful supplement in an area of limited woodland fuel resources.

Burnt peat fragments are a common discovery on Bronze Age settlement and burial sites in Orkney and Shetland, with wood charcoal rare or limited in range of species. Heathy turf or peat was extensively used as the main source of fuel at this time. Botanical analysis of samples from the barrow at Mousland, Orkney (Dickson et al 1994) also produced wood charcoal of birch. The burials at Linga Fiold, Orkney produced large quantities of birch branches, probably used as funeral pyres, with a small amount of alder twigs (Alldritt 1996). The use of wild plant resources as fuel and for construction purposes is important in terms of optimizing resources in an island environment (eg Bond 1994a; Smith \& Mullville 2003). 


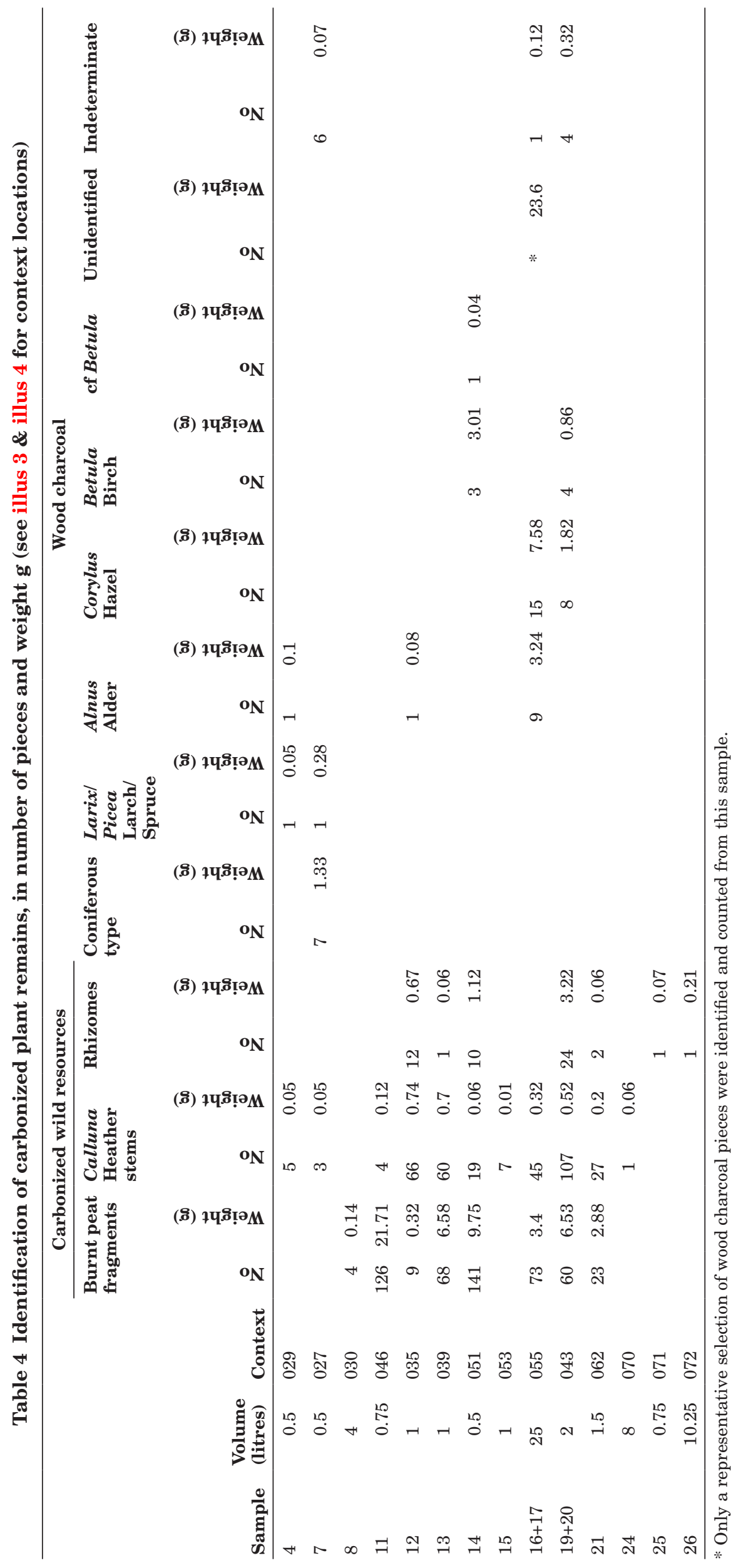




\section{The Technical Characterization of Cramp by Effie Photos-Jones}

\subsection{Introduction}

The purpose of this analysis was to elucidate the nature and composition of the vitrified fuel ash waste (VFAW) or cramp recovered from the site, if possible, by: a) identifying the key elements that characterize cramp; b) identifying the key ingredients of cramp, such as soil, bone, fuel and fuel ash, and in what combination they occur; c) identifying any key elements that characterise each ingredient; d) identifying how the ingredients contribute to the formation of cramp; e) identifying the conditions (eg temperature, duration of heating) which prevail in the course of cramp formation and what parameters contribute to its vitreous state and extensive porosity; f) comparing the cramp's chemical and mineralogical composition to cramp examined from other sites.

\subsection{Weight, size and texture}

A total amount of $c 1348 \mathrm{~g}$ of cramp has been collected from all contexts (including $900.5 \mathrm{~g}$ from the topsoil over Structure 1). From the area of Structure 2, the combined contents of Cist 006 produced the largest quantity $(c 356 \mathrm{~g})$, with the second largest amount retrieved from the topsoil ( $c 65 \mathrm{~g}$ ). The amount of cramp recovered from all the remaining features is a fraction of the total (Table 1).

The Loth Road cramp is predominantly dark grey in colour and consists of a light, frothy, highly siliceous vesicular material comprised of small spherules with a glassy skin. The average particle size is less than $1 \mathrm{~cm}$. Fill 030 in Cist 006 produced cramp of a larger size (3-4cm along the long axis). Larger cramp particles are probably formed as the result of many smaller particles having been scooped together and deposited while still hot. The cramp retrieved does not always reflect the original shape, volume or weight of the material.

All pieces, large or small, have a glassy skin covering a porous and particulate under-surface, which is in places glassy and in others only partially heated and therefore very friable. As such the contents of some bags appeared to be filled with soil, but in fact contained cramp which has never reached vitrification, in other words, soil and fuel ash. Evidence from other sites suggests that cramp will form as a multitude of spherules fused together (Photos-Jones 1999; Photos-Jones 2001; PhotosJones 2003a; Photos-Jones 2003b). Vesicularity arises from gas evolution, either of organic matter or $\mathrm{CO}_{2}$. Bone appears to be engulfed by the fused glass either in small fragments visible to the naked eye or micro-particles visible only with the microscope.

\subsection{Analytical methods}

\subsubsection{ICP-OES analysis}

Inductively coupled plasma optical emission spectroscopy (ICP-OES) analysis of cramp provides bulk chemical composition as well as providing elemental composition of major, minor and trace elements, pinpointing the potential fingerprint elements associated with each ingredient, such as soil and bone.

\subsubsection{SEM-EDAX analysis}

Scanning electron microscope analyses with energy dispersive analyser (SEM-EDAX) is based on both area analysis equivalent to bulk chemical composition and spot (single-phase) analysis. SEM-EDAX analysis was undertaken to establish the cramp composition and is particularly useful in the analysis of micro-phases, which can provide information on the mechanism of cramp formation.

\subsection{Results}

\subsubsection{ICP-OES analysis}

Four cramp samples were analysed from Structure 2 , all of them retrieved as finds. One was from the topsoil whilst the remainder were from the fills of Cist 006. The soils analysed were subsamples of nine bulk samples. Five were pit fills, one a box fill, three were from the fills of Cist 069 and one from Cist 006. This was the only context - 030, the secondary fill of the cist - from which both soil and cramp samples were analysed.

Analysis shows that the cramp is an iron aluminosilicate with small amounts of calcium, magnesium, potassium and phosphorus. This is consistent with cramp from other sites, such as the Knowes of Trotty, Kewing and Crantit (Photos-Jones 2001; PhotosJones 2003a; Photos-Jones 2003b). The similarity between the composition of the soil and the cramp samples is strong. Elements like silica, alumina and iron are instrumental in cramp formation, as well as trace elements like barium. Given these similarities, it is clear that the major component in cramp formation is the quartz-rich soil found within the pits and cists. The assimilation of bone, a calcium phosphate (hydroxyl-apatite), within the glassy 
matrix can contribute to cramp formation and this would be reflected in the relative concentrations of calcium, phosphorus and strontium. However, calcium and phosphorus could come from other sources, such as soil or fuel.

\subsubsection{SEM-EDAX analysis}

Area analyses for 'bulk' chemical compositions were carried out on the four cramp samples, confirming the results of the ICP-OES analyses. The SEM-SE images of the sample from Fill 026 in Cist 006 show a glassy matrix enveloping un-reacted or partly assimilated quartz grains; porosity is extensive and the glass is not uniform. Two of the micro-phases illustrate the behaviour of the cramp glass during cooling, one reflecting a liquid high in silica and alumina (glass), and the other high in phosphorus and iron (bone). This liquid immiscibility clearly points to the cramp having been molten as the two phases separate as the liquid cools.

The study of micro-phases can resolve a number of questions, including to what extent the phosphorus derives from the break-up of the bone or from another source or both. Plotting of molecular weights in a ternary diagram consisting of $\mathrm{CaO}-\mathrm{SiO}_{2}-\mathrm{P}_{2} \mathrm{O}_{5}$ (Photos-Jones et al, in prep) shows that the ratio of calcium to phosphorus is consistent with that of bone. However, at times there is either excess calcium or excess phosphorus, indicating that both calcium and phosphorus can be procured by different sources in addition to bone. An additional source for phosphorus could be minerals concentrating within peat and turf. SEM-SE images of a cramp sample from the Knowes of Trotty (KOT9, from context 044) point to the presence of a glassy matrix, small fragments of bone and cellular plant matter trapped in the glassy matrix, with mineral inclusions of aluminium, phosphorus and iron (Photos-Jones 2003b).

\subsection{Conclusion}

The results show that the key ingredient in Loth Road cramp formation is quartz-rich soil. Other materials - bone, fuel and fuel ash - are incorporated by the cramp and may also contribute to cramp formation. One component missing from the results of the analysis is fuel ash. However, we would argue that seaweed ash is the key ingredient in glass formation, because of its relatively high alkaline content, acting as a flux to lower the temperature at which the silica in the quartz or sand grains fuses or melts to form the cramp (Photos-Jones et al, in prep). 


\section{Comment on the Pottery by Ann MacSween (with additional note by Paul Sharman)}

Five undiagnostic body sherds (SF17, 20g), all from the same vessel, were recovered from context 059 below the wall of Structure 2. The sherds are undecorated and $12 \mathrm{~mm}$ thick. The fabric is fine sandy clay with c $50 \%$ of angular rock fragments up to $10 \mathrm{~mm}$ long, which has fired hard and is red with a grey core.
Three more undiagnostic body sherds (3.55g), which were very similar to those described above, were recovered from S14 from context 051, the primary fill of Pit 050 . 


\section{Coarse Stone Report by Ann Clarke}

\subsection{Description}

\subsubsection{Flaked stone bars}

Five flaked stone bars were found (illus 9), bearing the typical range of characteristics that are standard to these types (Clarke 2006, 25-33; Clarke forthcoming). Four were made from tabular blanks of sandstone, which were then flaked around the edge to form the required shape, usually a tapering rectangle, with asymmetrically curved working ends. One flaked stone bar was made from a long cobble (SF12) and a spread of pecking across one face is evidence that it was hafted for use. This was the only piece to show signs of use, with rounding and flaking at the working end.

\subsubsection{Ard}

One broken ard point was found (illus 9). It is flaked all round to form a thick cross-section, has a squared

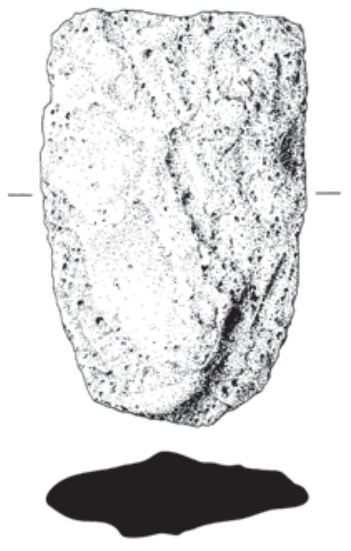

SF 3

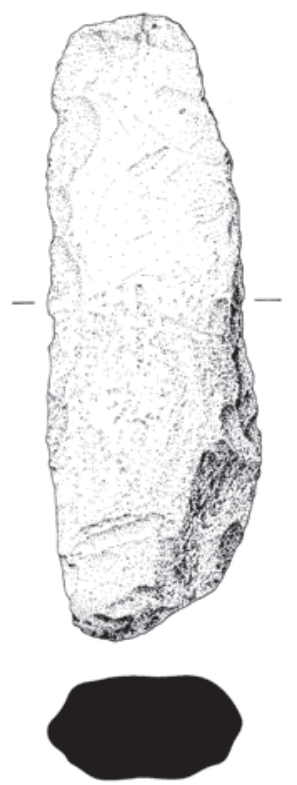

SF 12

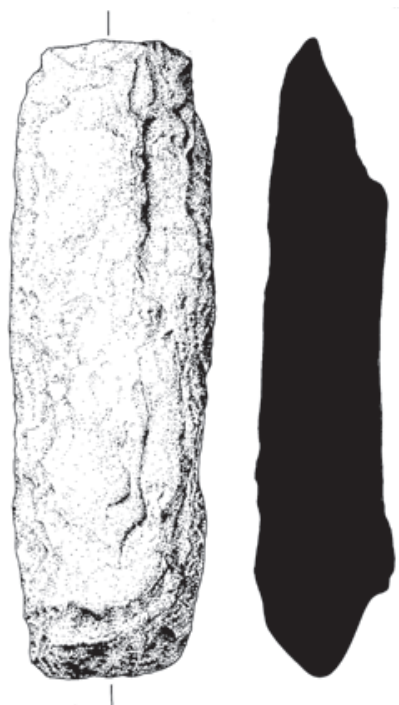

SF 10

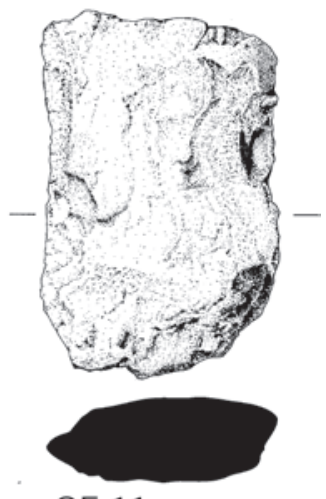

SF 11
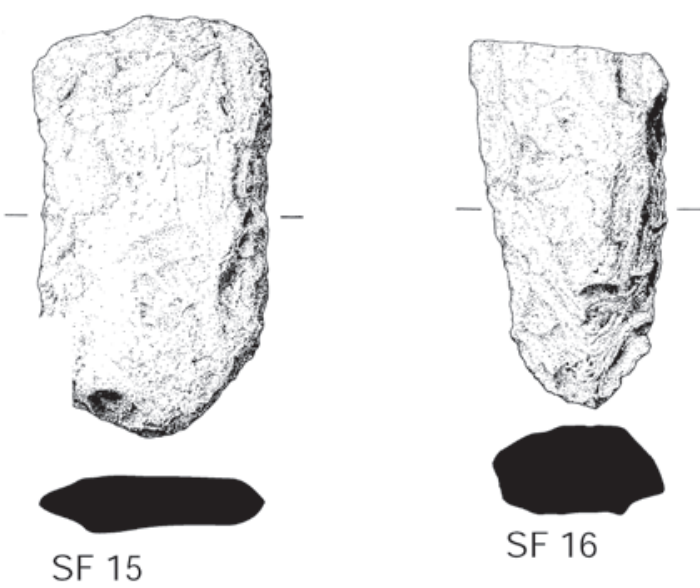

SF 16

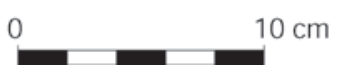

Illus 9 The coarse stone tools 
butt and traces of smoothing survive. The working end is very damaged. All indications are that it was broken in use.

\subsubsection{Flint}

One secondary flint flake with a scalar platform was found. All the edges are rounded and the surface is glossy, as if from long-term exposure or rolling.

\subsubsection{Flaked flagstone}

A large stone disc (SF20) was used as a lid for the steatite vessel in Cist 069. The pot lid is $350 \mathrm{~mm}$ in diameter and is finely made with bifacial flaking around the circumference to shape a circular outline (illus 5). The base (073) from this cist was in three fragments, two of which are clearly from the same slab and have been bifacially flaked to form a broad curve.

\subsection{Context}

All of the flaked bars, the ard and the flint were associated with the mound material. Four of the flaked stone bars (SFs 11, 12, $15 \& 16$ ) and the secondary flint flake (SF21) were from context 002, the layer of pebbles sealing Structure 2. The other flaked stone bar (SF3) was from the topsoil above Structure 2. The ard point (SF10) is from the turfy, humic layer (context 001). The flaked flagstone items are from the earliest phase, from Cist 069.

\subsection{Discussion}

Flaked stone bars (or mattocks) and ard points are common finds from Bronze Age kerb cairns. The recent excavations at Linga Fiold had over 50 flaked blanks, which were deposited primarily around the kerbs or edges of the cairns (Clarke forthcoming), and in this respect their deposition differs to Loth Road, where the flaked blanks were found within the capping material.

The $350 \mathrm{~mm}$ diameter stone disc (SF20) was used as a lid for the steatite vessel in Cist 069. A stone disc was also used to seal a steatite urn containing cremated bone in a cist at Orem's Fancy, Stronsay (Petrie 1870, 348). The large size of the disc tends to be a pre-Iron Age trait, as at Pool, Sanday (Clarke 1998, 145-6). Such large discs usually overhung the vessel (Clarke 1998), as it did here (the urn had a maximum diameter of $320 \mathrm{~mm}$ - see Sharman below). Other stone discs have been found in late Neolithic and Bronze Age funerary contexts in Orkney, as at Sand Fiold, Queenafjold and Linga Fiold (Ritchie \& Ritchie 1974, 35; Dalland 1999, 382-3; Clarke forthcoming). The placement of the inurned cremation on slab fragments bifacially flaked to a curve is reminiscent of the placement of the cremation deposit on a $250 \mathrm{~mm}$ diameter bifacially flaked stone disc in Mound 9 at Linga Fiold (Downes forthcoming). 


\section{The Steatite Vessels by Paul M Sharman}

\subsection{Introduction}

The remains of two steatite vessels were found at Loth Road. SF18 comprised 19 small fragments (289g) found in Fill 066 in Pit 068, which was sealed by the kerb wall. SF19 was a complete though broken vessel found in Cist 069, containing one of the two major deposits of cremated bone from the site.

\subsection{Description of SF18}

Four rim and 15 wall fragments were recovered. Although very few joins have been noted between them, they all appear to be from the same vessel.

\subsubsection{Size and shape}

It is probable the vessel was sub-four-sided with curving corners and slightly curved steeply angled walls flaring upwards to form a wide-mouthed vessel. No base fragments were recognized. The chipped vessel rim is flat to slightly convex. The size of the vessel is unknown, but it was comparatively small, probably less than $200 \mathrm{~mm}$ across.

\subsubsection{Stone and condition}

The steatite used is pale to mid shiny grey, finely laminated and micaceous, with other evenly spread mineral inclusions. The fragments are small, with almost half of them in moderately good condition, whilst the others are beginning to crack or fall apart along the natural laminations. The breakage surfaces are mostly moderately crisp. The rim and external wall faces are a little worn and sometimes so abraded that tool marks are no longer visible.

\subsubsection{Tooling}

Initially, the outside of the vessel was roughly shaped, reflected in its undulating surface. Where not worn and abraded, the exterior is covered in linear tool marks, similar to those on the interior, which are clearest near the rim. These are overlaid by faint scratches from smoothing by an abrasive material, as is the rim. The linear marks, which often overlap, comprise single V-shaped lines and lines of two closely set parallel scratches. The marks tend to be vertical or diagonal, becoming more horizon- tal towards the rim on the interior. The overlapping, variable direction and spacing indicates that the tools were handheld to gouge, whittle and incise.

\subsubsection{Accretions}

The rim and exterior of the vessel are virtually clean. Inside the vessel there are small, faint traces of dark stains near the inside of the rim. Most of the rest of the interior is coated in a dark grey-black material less than $1 \mathrm{~mm}$ thick, overlain by lumps and cracked layers of $2-4 \mathrm{~mm}$ thick grey-black accretions. Two thick accretion lumps adhere to break faces.

\subsection{Description of SF19}

The vessel (illus 5; illus 10) was broken in situ into eight major fragments with several small chips. A triangular piece measuring $22 \mathrm{~mm}$ wide at the top by $30 \mathrm{~mm}$ high is missing from the rim.

\subsubsection{Size and shape}

The lop-sided wide-mouthed vessel is almost circular, with slightly convex steeply angled walls $8-18 \mathrm{~mm}$ thick. Internally it is $159-178 \mathrm{~mm}$ deep and measures 290 by $304 \mathrm{~mm}$ across at the mouth and 185 by $195 \mathrm{~mm}$ at the base. The rim is flat-topped, with a smoothed $2 \mathrm{~mm}$ deep recessed band $5-14 \mathrm{~mm}$ wide around the top of the external wall, which disappears where the rim dips down. The internal and external base surfaces undulate slightly, the latter contributing to the vessel's lop-sided appearance.

\subsubsection{Stone and condition}

The steatite used is pale-mid grey, with a pale-mid brown tinge. It is moderately coarse, with poorly sorted mineral inclusions and finely laminated with four major cleavage planes, roughly parallel with the rim. The fabric is in remarkably good condition and the breakage surfaces are crisp, as are the rim and the tool marks on the walls. Cracks have formed, inherent to the nature of the stone, one of which is pronounced, located along the most significant cleavage plane. This has left a weathered-looking gap on the outside if a vein of weaker stone or patch of minerals has eroded out. There are minor cracks and spalling in the surface of the internal base and a small piece has broken off the edge of the external base along a lamination, probably during the process of manufacture. 

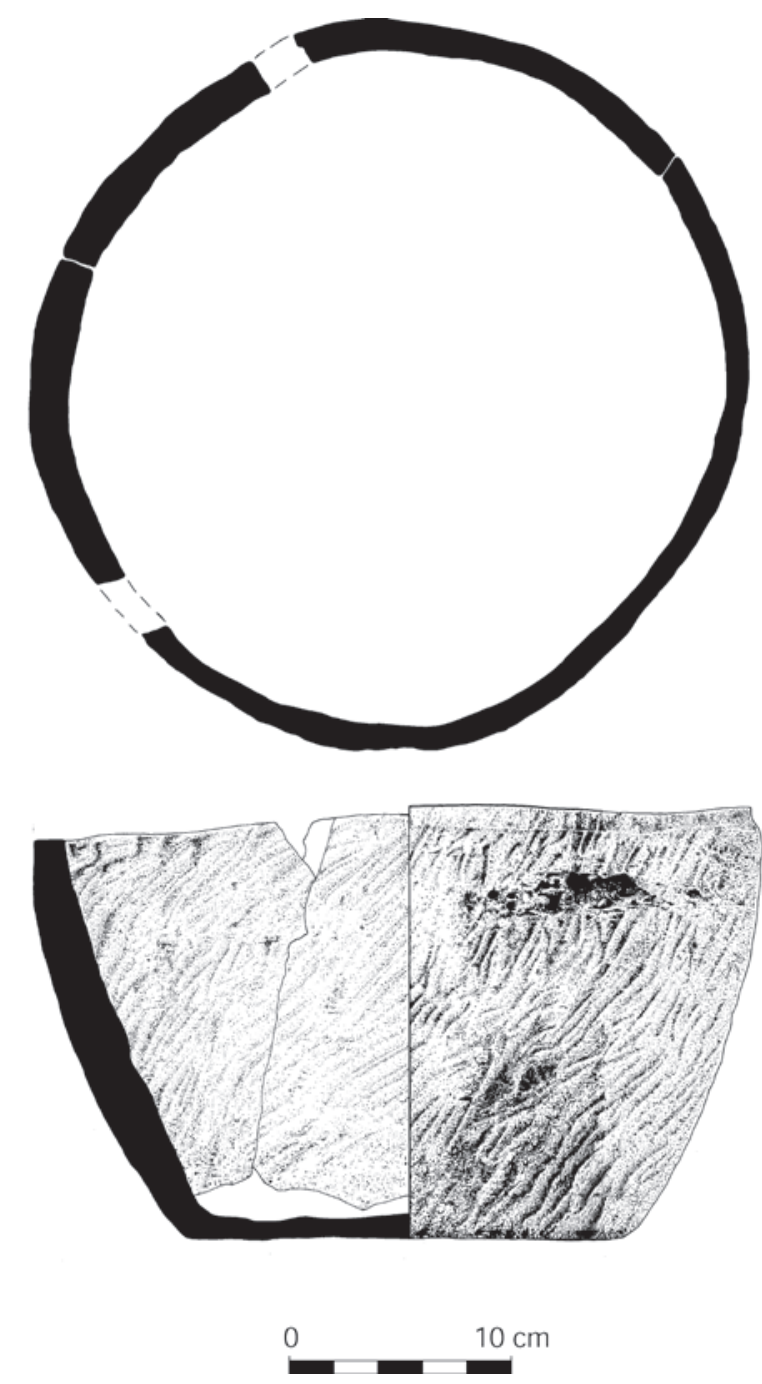

Illus 10 Steatite vessel SF19

\subsubsection{Tooling}

The outline shape of the vessel was chipped or flaked, leaving faint facets and dents, which are overlain by linear U-shaped tool marks that completely cover the external and internal walls. Internally, there are also some closely set parallel scratch marks. The marks on the internal and external bases are similar but more random than those on the walls. Externally, the marks sweep diagonally from the base becoming near vertical towards the rim. Internally, the marks are oriented diagonally from top to bottom, sometimes ending in the basal surface. The depth, length and spacing of the external marks are less variable than those on the internal wall, probably because it was more difficult to work the interior, due to the constricted space. The marks, which are crisp on the exterior and slightly blurred inside the vessel, have been created in a percussive manner, as with a hammer and chisel. Externally, the tool marks cross the flaw in the stone, as if the area eroded after the vessel was created. However, internally, the marks change direction to avoid the crack, which is surrounded by sharp, V-shaped lines or grooves, created by a handheld tool. Around the top of the interior wall there is a band of short, closely spaced tool marks, veering to the horizontal, that neaten up the inside of the rim.

There are traces of incised guidelines for the creation of the band around the outside of the rim, which cut through the linear tool marks on the wall face. The band was ground smooth, leaving faint horizontal scratches. Most of the top surface of the rim was smoothed flat, except for a small area that presented slight facets along surface, probably from whittling the rim into shape. A short length of the rim (the lowest part) broke off along a lamination, probably during manufacture, corresponding to the disappearance of the external band and incomplete tool marks.

\subsubsection{Accretions}

Much of the external wall is stained, presumably with ash or soot, which does not enter the eroded flaw. The creation of the smoothed band has removed the black stain at the top of the wall. There are no other accretions on the vessel.

\subsection{Discussion}

\subsubsection{Source}

Steatite (or soapstone) is the general name for a variety of soft, metamorphic talcose rocks with variable lesser amounts of other minerals (Highley $1974,3)$. It does not occur in Orkney and although found in sporadic outcrops in the west of the British Isles (Highley 1974, 6-11), the major and closest source of steatite in this area is the concentration of outcrops in Shetland (Moffat \& Buttler 1986, 103, fig 1). Recently, there has been some success in developing provenancing techniques to distinguish between potential sources of steatite in the region (Jones et al, forthcoming), but it has not been possible to apply these analytical methods to the Loth Road vessels. Therefore, the unsatisfactory method of examining the macroscopic appearance of the stone (combined with experience of a range of artefacts and samples from outcrops) has been applied to the vessels to identify their possible source (Moffat \& Buttler 1986, 114).

The sub-four-sided vessel form of SF18 seems to be peculiar to vessels made in Shetland, in both the prehistoric and Norse periods, probably as a response to the nature of steatite found here (Sharman 2000, 85). The steatite used for vessel SF18 certainly appears to be within the range of stone found in Shetland, but does not appear to be from Catpund. The steatite used for vessel SF19 is most similar to the range of stone found at the Catpund outcrop, or 
perhaps in Fetlar, because of the colour, the coarse, ill-sorted mineral inclusions and the pronounced cleavage planes. It does not seem to be similar to the stone found at the other main sources in Shetland, such as Clibberswick in Unst or Fethaland in North Roe (Moffat \& Buttler 1986, fig 1). Catpund is by far the largest outcrop of steatite in Shetland, outweighing all the other sources combined (Moffat \& Buttler 1986, 102). However, it has been suggested that the quarry sources in the northern isles of Shetland were more active in the prehistoric period (Forster \& Sharman in prep), thus it is possible that the vessels were made from one of these sources.

\subsubsection{Manufacture}

There is no evidence at Bronze Age settlement sites for the manufacture of steatite vessels. It is most likely that they were made at the quarry, as in later periods, because they were liable to break during manufacture (Forster \& Sharman in prep). SF19 clearly shows this problem and how likely it is that the vessel was produced at the quarry. The flaw that is an eroded pocket on the outside of the vessel was carefully worked around on the inside to prevent the vessel from breaking. Despite this, a small part of the rim broke off along another lamination at a very late stage in the manufacture of the vessel, during or after the creation of the smoothed, stepped band around the rim. Small flakes have also broken off the base. These minor mishaps would have occurred during manufacture because the broken surfaces are as abraded and/or patinated as the rest of the vessel.

Both vessels bear indications of the types of tool used during their manufacture, such as blades, points, hammers and abrasives. This toolkit was within the technology of the period, both in Shetland and Orkney (Øvrevik 1990, passim; Fojut 1994, 24 36) and such marks have been noted on many other broadly contemporary vessels, both domestic and funerary. The variability in the form and tooling of such vessels, reflecting a wide range of skill levels, indicates that they were not made by full-time professional workers, but were the result of part-time or domestic exploitation.

\subsubsection{Function}

The primary function of SF19 was as a funerary vessel for cremated human remains, shown by its condition, contents and context. Many steatite funerary vessels are highly burnt and falling apart from placement in the intense heat of a pyre (Sharman in prep), but that is not the case with SF18, which presents evidence that it was used in a domestic setting prior to its burial. The thin burnt lining may be the result of sealing the vessel to reduce its porosity, overlain by thick accretions from cooking foodstuffs. The condition of the vessel indicates that it had been used on a fire several times, with burnt material entering the cracks that gradually appeared from such use, similar to the fragments from the settlement site of Tofts Ness, Sanday (Smith in prep). However, the possibility that the vessel had been used many times in funerary activities such as feasting cannot be excluded.

Although in Shetland, steatite vessels similar in form were produced for both domestic and funerary purposes, in Orkney almost all have been found in mortuary contexts (Sharman 2000, 65-6; Sharman in prep). It is possible that some vessels (perhaps SF18) could have been curated, even used, in a domestic context before deposition at a funerary site (Smith in prep). However, the evidence indicates that such vessels were regarded primarily as funerary items in Orkney, perhaps produced specifically for this market (Øvrevik 1990, 145).

\subsubsection{Form, parallels and dates}

The vessels, though different in shape and manufacture, sit within in a general Bronze Age Northern Isles variant group of ceramic and steatite funerary vessels, which bear little resemblance to mainland British traditions (Sheridan 2003, 213). The steatite examples of the Northern Isles group are so variable (probably because of the nature of the material) that no typology has yet been produced. They are usually dated to the Bronze Age by the typology of the funerary monument. Recently obtained radiocarbon dates for such urns have given a Late Neolithic/Early Bronze to Middle Bronze Age range of 2350-1400 BC, excluding the surprising exceptions of the Early Iron Age urns from Uyea, Shetland and the Late Iron Age urn from near Stromness, Orkney (Sheridan 2003, 213; Sheridan forthcoming). The vessels from Loth Road add to a growing body of dated evidence of a funerary tradition that until recently was categorized by vague typological parallels only.

The treatment, approximate size and shape of SF18 is paralleled at settlement sites by vessels from Early Bronze to Early Iron Age contexts at Sumburgh airport, Jarlshof and Bayanne in Shetland and Tofts Ness, Sanday (Curle 1935, 93; Hamilton 1956, 20; Sharman 2000, 66; Forster in prep; Smith in prep). Fragments of vessels probably similar in size to SF18 have also been found at mortuary sites. The best example is a sub-four-sided vessel (recorded as irregularly oval) found in a cist below a mound at Quandale, Rousay (Grant 1937, 78-9). The cremated bone from this has produced an Early Bronze Age radiocarbon date of 2150-1880 вС (Sheridan 2003, 222).

The round wide-mouthed bucket shape of SF19 is one of the neatest examples of this form, which can be rather lopsided and vary from sub-four-sided to oval to round in shape. Vessels of this general size and variable shape have been found at many sites, all of them funerary. Most of them were in cists from barrows or cairns and most contained 
cremated bone or were associated with inhumations. Examples include vessels from Muckle Heog in Unst, Shetland, one from Shapinsay, the dated vessel from Quandale, Rousay (Roberts 1865, 296-8; Donations 1882, 13-14; Grant 1937, 77-8). The cremated bone from another similar vessel from Rousay has also been radiocarbon dated, to 1740-1500 BC (Anderson 1883, 71-2; Sheridan 2003, 222-3).

The nearest parallels to the rim treatment on SF19 are two unstratified rim fragments from Taverso Tuick, Rousay, probably derived from secondary (Bronze Age) interments at the Neolithic tomb (Grant 1939, 163; Davidson \& Henshall 1989, 61 ) and a rim fragment from the Bronze Age (not
Neolithic - see Downes 2000, 121-2) Benie Hoose building, Whalsay, Shetland (Henshall 1961, 41-3).

No attempt has been made to smooth out the tool marks on SF19, which is highly unusual for a funerary vessel (Sharman 1999). Sharp tool marks are more common on domestic vessels, such as those found in a Late Bronze Age building at Jarlshof in Shetland (Curle 1935, 92-3). The clear, neat tool marks, especially on the exterior, may have been intended as a decorative treatment to enhance the appearance of the vessel. However, they could have simply been regarded as unimportant, irrelevant to the function of the vessel and the aesthetics of the period. 


\section{Discussion}

The excavations at Loth Road have revealed some of the physical remnants of what may have been an extensive and prolonged series of events that comprised the funerary ritual (Downes 1999a). Cremation, burial of selected remains and the construction of a monument are the most obvious archaeological parts of these events.

\subsection{Mortuary activities and products}

\subsubsection{Cremation}

Although the actual site of the pyre(s) was not observed within the area of excavation, some evidence of the cremation was retrieved. From the analysis of the bone it is difficult to conclude anything other than that the remains of only two people, an adult and an infant, were interred here with the remains of perhaps two pyres. They were cremated while bearing flesh, not long after death.

There were localized temperature differences within the pyre, shown by the presence of partially assimilated quartz grains in some of the cramp, indicating a temperature of $600-800^{\circ} \mathrm{C}($ Carter 1997,10$)$ and by the glassy skin on others, indicating a temperature of $1000-1100^{\circ} \mathrm{C}$ (McKinley \& Kibble 1999 , 402). However, the pyre was clearly built by people who had the technical knowledge of the various factors that contribute to a 'successful' cremation, such as the size and stability of the pyre, the type and quantity of fuel, the circulation of oxygen, the correct placement of the body, so that it was constructed so that it burnt with a prolonged and high temperature, of sufficient heat to reduce the bodies to cremated bone (McKinley 1997, 132-4).

\subsubsection{Fuel}

The fuel used for the pyre comprised the only naturally available materials in the island (Hedges 1977, 143) - peat, supplemented by heathy turf and some wet fen material, laced with scrub and some driftwood. Body fat would also have acted as fuel. Although the site dates to a period of peat formation and woodland decline, the result of Neolithic activities and climatic change (Davidson \& Jones 1990, 25-32), peat and other quality fuels have always been limited resources on Sanday (Bond 1994b, 129), so it is noteworthy that peat dominates the fuel types, over the remains of heathy turf for example.
There is evidence for the Neolithic and Bronze Age use of seaweed as a fuel, fertilizer and a contributor to cramp formation from Tofts Ness in Sanday, Mousland cairn near Stromness and Barnhouse, Stenness (Bond 1994b, 129-30; Milles 1994, 123-4; Stapleton \& Bowman 2005, 383-4). There are also written references from the 16th century AD onwards that those inhabitants of Sanday who could afford it obtained peat from neighbouring islands, especially Eday, whilst others made do with sandy turves, dried cow dung, straw and dried seaweed (Fenton 1978, 206-10). However, some analyses indicate that it may be possible for cramp to form simply because high enough pyre temperatures were attained to fuse the silica in sedimentary material without using seaweed or seaweed ash (eg Carter 1997, 11-13).

\subsubsection{Collection and deposition}

The collection and interment of remains from the pyre was not simply a matter of collecting enough bone to represent the body and burying it in a pit, cist or urn, perhaps with some other pyre material included by accident. Recent research and excavations at Bronze Age funerary sites such as Linga Fiold have shown that pyre debris was sorted and deposited in different ways, that many features can be associated with the same cremation (Downes 1995, 399; McKinley 1997, 137-9; Downes forthcoming b).

A comparison of the material found in each sampled feature at Loth Road shows a significant difference in what was deposited in cists, pits and boxes, and sometimes between features of the same kind (Table 1). It is clear that the pyre remains were picked over, sorted, collected and deposited in different ways and, from the size of the cramp in Cist 006, while some of it was still hot. Collectively, the deposits comprise all aspects of pyre remains. The evidence indicates that the pits, boxes and cists are contemporary and should be looked at as a whole (cf Downes 2006).

Carbonized wild fuel resources, such as peat and turf, are the predominant remains in many of the pit fills, some of which contain so few pieces of other materials that that they may have been accidental inclusions (McKinley 1997, 137). However, other deposits are different. One pit contains virtually nothing at all (that has survived), one a large deposit of wood charcoal and one a block of stone. Another contains steatite vessel fragments, one a comparatively significant amount of bone and yet another a large amount of cramp. The pit fills appear to be formal and specifically chosen deposits in deliberately cut features (McKinley 1997, 139). 
The 'boxes' contain a comparatively even mixture of fuel remains and cramp. However, the amounts are so small that these might not have been the significant elements of the deposit.

Cramp and cremated bone dominate the cist fills. It is significant that the major collections of cramp and bone were deposited together, treated in a similar fashion as if of similar importance. This is no accident, as people were clearly capable of sorting one material from another and collecting them separately (Downes 2006). In some of the pits, the few fragments of cramp present can be explained as accidental inclusions, but in others, such as Pit 060 where 30 pieces were retrieved, cramp must have been an intentional part of the deposit. This selective treatment of cramp has been noted at other sites, such as Linga Fiold (Downes forthcoming). For example, in one of the features, cramp that contained visible bone fragments was deposited with the cremated bone, whilst cramp with no visible bone was placed on top of the slab that sealed the bone deposit (Carter 1997). Downes concludes that cramp chosen for burial with cremated bone or with other pyre debris is the result of the differential selection of cramp according to its proximity to the body (Downes 2006).

The cists are the major repositories of human remains at Loth Road and should probably be regarded as the primary burials. The cremated remains of a person were rarely, if ever, fully collected for burial (McKinley 1997, 137), but the amount at Loth Road is small indeed. It is a fraction of what is considered to form primary burials (McKinley 1997, 139-42), yet the manner in which the bones have been deposited display many of the traits of primary burials - they form the largest bone deposits on site, they have been placed in cists and one deposit forms the primary fill of an urn. One could claim that this was all the bone that was sorted and collected from the pyre remains, perhaps reflecting the standing of the deceased (McKinley 1997, 142). However, it is more precise to claim that this is the amount of bone that was chosen to be buried at this site and we do not know what happened to the remainder, which may have been abandoned, or may have been curated, utilized or disposed of in many different ways.

It is possible that Cist 069 contains the remains of a double burial, but the adult bone was retrieved from contaminated fills and must be discounted. However, perhaps one could interpret the site as a whole as that of a double burial, because the primary feature of these in Bronze Age Orkney (with one exception) is that of the pairing of an adult with an immature individual in the same feature (Downes 2006). At least six instances of such a pairing were found at Linga Fiold and several others have been found during excavations by the Orkney Barrows Project, including the sites of Gitterpitten and Varme Dale (Roberts 2000; Downes forthcoming).

Although experimental work has shown that it was quite feasible to collect the remains of two indi- viduals cremated on the same pyre without mixing them up (McKinley 1997, 134), and much of the discussion above militates towards a single pyre, it is quite possible that, because the remains of the adult and the infant were interred separately, they were cremated individually. The details of their contexts are also distinct. Cist 006 stands proud of the contemporary surface, whilst Cist 069 is level with it. Cist 069 contains an inurned cremation burial, whereas Cist 006 does not. Cist 069 was capped before the kerb was built, whilst the fills of Cist 006 were sealed afterwards. Whether these people were cremated separately or not, it was considered appropriate to bury some of their remains at the same site.

Other materials were also regarded as significant enough for interment or placement at the site, such as the pottery fragments from Pit 050 and Spread 059 and the steatite vessel fragments from Pit 066. These may have been grave goods, because there is no evidence that these artefacts had been in the pyre.

\subsection{Ritual, display and commemoration}

Shortly after the features had been filled or sealed, a cairn was built on the site, starting with a freestanding circular kerb, which was infilled with rubble and capped by a layer of imported gravel and pebbles (illus $7 \& 8$ ). None of the burial features were enclosed or contained by the kerb wall and there was no apparent entrance. Although it appeared to be placed haphazardly over the pits, it did seem to take cognisance of the two cists, which in effect were incorporated into the outside of the structure. The close association of the cairn with the pits and cists leads to the conclusion that it acted as a memorial or marker for the burials. This is a slight variation on the usual layout of Bronze Age mounds and kerbed cairns in Orkney, which are usually centred over a cist, or may even contain one. The cairn was in a prominent location, with an extensive view (illus 2), visible to a wide area of the local population as well as community that built it.

Part of the funerary ritual appears to include the placement of certain artefacts, whether significant in themselves or as metaphysical symbols. The flaked flag fragments at the base of the cist, and especially the flaked stone disc or pot lid that sealed the urn, represent the time and skill of the person who made them and are associated with the containment of the deceased. The pottery and soapstone vessel fragments (SF18) appear to have been deliberately interred, perhaps as grave goods, or as part of the formal disposal of pyre remains or other rituals. The complete soapstone vessel was used as an urn for someone's cremated remains. The value of steatite must be considered here - soapstone or steatitic pottery vessels may have been more prestigious than local ceramics, because of their rarity and cost, which included labour and transport. Even the 
broken fragments of SF18 must have been endowed with some value, reflected in their deliberate and formal deposition. The use of the complete steatite vessel as a cremation urn and grave good (not pyre good, see McKinley 1994, 133) must have conferred some status on the dead and/or the living who could afford to own it and then to dispose of it. It may be that wild resources were not husbanded with care at all, but it is possible that the use of limited resources, especially peat, reflects an element of lavish expenditure on the pyre.

Coarse stone tools often seem to play a part at Bronze Age funerary monuments in Orkney and the inclusion of agricultural implements especially seems to be an integral part of funerary ritual (Downes 1994, 150-1; Clarke 2006, 105-7). The possible cobble tool setting at Loth Road echoes a nest of three large used cobbles on the platform of Mound 7 at Linga Fiold (Downes forthcoming). The inclusion of coarse stone tools on the site, mostly associated with its final capping in the mound material itself, is not because they have been discarded, but because their function has changed, they are no longer simply agrarian implements.

\subsection{The Orcadian context}

The site fits firmly within a dated sequence of Early-Middle Bronze Age Orcadian funerary monuments (Ashmore 2003, 35, 44-5) and shares many traits that are part of a common tradition of ritual behaviour, exemplified by the results of the recent excavation of the cemetery at Linga Fiold (Downes 1995; Downes forthcoming b). The site's highly visible location on land marginal to agriculture is typical of many in Orkney (Hedges 1977, 140), but the small size and type of cairn construction is less so, although this may be due to what has been excavated so far. The freestanding kerb, faced on both sides, is less common than the more usual construction of a kerbed cairn with a low outer face only, capped by turf and earth scraped up from the surrounding area (Barber et al 1996, 116). Two such freestanding kerbs were found at Linga Fiold to the north of Mound 7, centred over pits containing pyre material (Downes 1995, 399 plan \& pers comm). Two more have been excavated in the Rendall area, one at Varmedale and another at Gitterpitten, both with central cists (Downes 1999b, 11, 16, illus 3, 8, 15b).

The differential burial of sorted remains, including cremated bone and the construction of a cairn over these with the deposition of agricultural implements is paralleled at sites such as Linga Fiold and the Knowes of Quoyscottie (Hedges 1977; Downes 1995). The work at Linga Fiold has resulted in the recognition of such details in and differences between deposits, that all features containing bone do not necessarily represent an individual cremation, thus helping in the re-interpretation of older excavations, as at the Knowes of Quoyscottie (Downes 2006).
Most of the sites quoted as parallels comprise pairs or groups of mounds. At Loth Road, it is possible that the mound of Structure 1, originally thought to be a clearance cairn, is actually a funerary monument. The large amount of cramp found over this area is reminiscent of the observation of large amounts of cramp on mounds, 'plentiful in certain parts of Sanday, as at the south end of the Els Ness peninsula, where a group of burial mounds were literally covered with it' (Callander 1936, 445). Site 20, the mound to the west, may be another Bronze Age mound, forming a group of burial monuments at Loth Road (Hunter \& Dockrill 1991, 7-8).

\subsection{The living}

Many aspects of the site at Loth Road reflect the living as well as the dead. The fuels used for the pyre indicate the sources available for daily life. The flint, the marks on the steatite vessels and the agricultural implements are indicative of part of the toolkit available for subsistence activities and products of the period. Extensive remains of the farming represented by the ard point and sandstone bars have been recovered at the other end of Sanday, on Tofts Ness, where evidence Neolithic and Bronze Age clearance, ploughing, cereals and manuring has been found (Dockrill et al 1994; Simpson 1998).

The site is on land considered to be marginal to agriculture, placed in order to avoid arable land, with the implication that this was more valuable (Hedges 1977, 152). However, in a period of climatic deterioration in an environment that was marginally viable in general (Bond 1994b, 130-1), heath land would also have been valuable as grazing land and a source of turf, a fragile resource that required careful husbanding (Downes 1994, 152). Survey has identified several prehistoric field boundaries, settlement sites and burnt mounds on Spurness, some of which will be contemporary with the cairn (Hunter \& Dockrill 1991, 6-9). These include a burnt mound and two settlements less than $500 \mathrm{~m}$ north of the site (Lamb 1980, sites 51, 89, 90; Hunter \& Dockrill 1991, sites 44, 52, 53; Orkney SMR OR 367, $366,365)$. The funerary monument at Loth Road stood not in isolation, but as part of the landscape of a living community, for the living to continue their relationship with the dead, perhaps perpetually vindicating their place in the landscape through the presence of their ancestors.

The steatite vessels at Loth Road, along with many others found across the islands, as well as Bronze Age ceramic urns made with steatitic clay from Shetland (Sheridan 2003, 213), reflect some of the more outward-looking aspects of the population, systems of trade, barter or exchange. Although the number of such vessels in Orkney is not huge, the radiocarbon-dated urns from Orkney indicate that the sea was crossed with some regularity over several hundred years. The route of communication 
was probably via Fair Isle, which is visible from both island groups, where a Bronze Age soapstone funerary urn has also been found (Hunter 1996, 27). Their presence implies the occurrence of other socio- cultural and artefactual exchanges between the two archipelagos (Øvrevik 1990, 144-5; Hunter 1996) and is a tribute to the boat technology and seafaring skills of the time. 


\section{Conclusion}

Funerary rites the world over confirm relationships between the living, and establish a different relationship with the newly dead. These relationships may not end with the burial, but continue long after in dialogues with the ancestors, in physical or incorporeal form. Rites of placation or supplication and rituals of remembrance may all have a part to play. The presence of the dead within the landscape of the living may help define the community, reestablish ancestry and ownership of the land. Some aspects of the start of the complex relationship between the living and the dead can be found in the archaeological record of funerary sites, as at Loth Road. 


\section{Acknowledgements}

Effie Photos-Jones wishes to thank Drs R E Jones and A Hall for their contribution to the ongoing research surrounding cramp; Julie Roberts of GUARD for parting with the Loth Road bones temporarily; Robert MacDonald, Earth Sciences, University of Glasgow and Gert Petersen for SEM and technical assistance respectively; Historic Scotland for continuing to fund research on cramp.

In connection with the soapstone report, Paul Sharman wishes to thank Judith Robertson, who weighed some of the fragments; Ian Bray, Amanda Forster, Hazel Moore, Graeme Wilson, Andrea Smith and Richard Jones for discussing their work and permission to refer to their material prior to publication; Alison Sheridan for discussing radiocarbon dates from the NMS Dating Cremated Bones Project and providing copies of her articles.
The analysis of the metal flake from the urn was facilitated by Dr Alison Sheridan and conducted by Dr Jim Tate, Conservation \& Analytical Research Department, NMS. The finds illustrations are by Jude Callister and the maps and plans by Angus Mackintosh with Judith Robertson. The photographs were taken by the excavators. Nick Card initiated the post-excavation project, organizing and commissioning the work. The report owes much to editorial comments by and discussions with Jane Downes, who allowed free access to her unpublished excavation reports and research.

The author has condensed all of the specialist reports from the originals, full copies of which will be deposited with the site archive in the NMRS. The finds have been allocated to the Orkney Museums Service. 


\section{References}

Alldritt, D 1996 A Report on the Charcoal and Carbonised Plant Macrofossils from Lingafold, Orkney, 1994. Unpublished report for GUARD.

Anderson, J 1883 Scotland in Pagan Times: The Iron Age. Edinburgh.

Ashmore, P J 2003 'Orkney burials in the first millennium AD' in Downes, J \& Ritchie, A (eds) Sea Change: Orkney and Northern Europe in the Later Iron Age AD 300-800. Pinkfoot Press, Balgavie, 35-50.

Barber, J, Duffy, A \& O’Sullivan, J 1996 ‘The excavation of two Bronze Age burial cairns at Bu Farm, Rapness, Westray, Orkney', Proc Soc Antiq Scot $126,103-20$.

Beijerinck, W 1947 Zadenatlas der Nederlandsche Flora. Veenman and Zonen, Wageningen.

Bond, J M 1994a Change and Continuity in an Island System: the Palaeoeconomy of Sanday, Orkney. Unpublished PhD Thesis, University of Bradford.

Bond, J M 1994b 'The faunal and botanical remains' in Dockrill et al, 1994, 128-31.

Bronk Ramsey, C 2001 'Development of the Radiocarbon Program OxCal', Radiocarbon 43 (2A), 355-63.

Buikstra, J E \& Ubelaker, D H (eds) 1994 Standards for Data Collection from Human Skeletal Remains, Arkansas Archaeological Survey Research Series No 44.

Callander, J G 1936 'Bronze Age urns of clay from Orkney and Shetland, with a note on vitreous material called "cramp", Proc Soc Antiq Scot 70 (1935-6), 441-52.

Carter, S 1997 Linga Fiold. Report on the Analysis of Slags from Cremation Pyres. Unpublished report for GUARD, Glasgow.

Clarke, A 1998 'Miscellaneous stone tools' in Sharples, N Scalloway: A Broch, Late Iron Age Settlement and Medieval Cemetery in Shetland, 144-9. Oxford (=Oxbow Monogr Ser 82).

Clarke, A 2006 Stone Tools and the Prehistory of the Northern Isles. Archaeopress, Oxford (=Br Archaeol Rep, Br Ser 406).

Clarke A forthcoming 'The coarse stone tools from Linga Fiold', in Downes forthcoming.

Curle, A O 1935 'An account of the excavation...of another prehistoric dwelling (No V) at Jarslhof, Sumburgh, Shetland...', Proc Soc Antiq Scot 69, 85-107.

Dalland, M 1999 'Sand Fiold: the excavation of an exceptional cist in Orkney', Proc Prehist Soc 65, 373-413.

Davidson, D A \& Jones, R L 1990 'The environment of Orkney' in Renfrew, C (ed) The Prehistory of Orkney. Edinburgh University Press, Edinburgh, 2nd edn.
Davidson, J L \& Henshall, A S 1989 The Chambered Cairns of Orkney. Edinburgh.

Dickson, C, Downes, J, McKinley, J I \& Hinton, P 1994 'The contents of the cist', in Downes, J 'Excavation of a Bronze Age burial at Mousland, Stromness, Orkney', Proc Soc Antiq Scot 124, 146-7.

Dickson, J H 1992 'North American driftwood, especially Picea (Spruce), from archaeological sites in the Hebrides and Northern Isles of Scotland', Revue of Palaeobotany and Palynology 73.14, 49-56.

Dockrill, S J, Bond, J M, Milles, A, Simpson, I, Ambers, J 1994 'Tofts Ness, Sanday, Orkney. An integrated study of a buried Orcadian landscape' in Luff, R \& Rowley-Conwy, P Whither Environmental Archaeology?, 115-32. Oxbow Books, Oxford.

Donations 1882 'Donations to the Museum', Proc Soc Antiq Scot 16 (1881-2), 10-15.

Downes, J 1994 'Excavation of a Bronze Age burial at Mousland, Stromness, Orkney', Proc Soc Antiq Scot 124, 141-54.

Downes, J 1995 'Linga Fiold', Current Archaeology 142, 396-9.

Downes, J 1999a 'Cremation: a spectacle and a journey', in Downes, J \& Pollard, T (eds) The Loved Body's Corruption: Archaeological Contributions to the Study of Human Mortality, 19-29. Cruithne Press, Glasgow.

Downes 1999b Orkney Barrows Project Stage 3: Fieldwork and Education. Unpublished ARCUS project report 245c.1 for Historic Scotland.

Downes, J 2000 'Architecture, spatial organisation and material culture', in Downes, J \& Lamb, R 2000 Prehistoric Houses at Sumburgh in Shetland: Excavations at Sumburgh Airport 1967-74, 117-28. Oxbow Books, Oxford.

Downes, J 2006 Cremation Rites and Technology in Bronze Age Orkney. Unpublished PhD thesis, Sheffield University.

Downes, J forthcoming Bronze Age Burials and Burial Rites in Orkney: an Account of the Linga Fiold excavations, the Orkney Barrows Project and Rescued Bronze Age Burials.

Fenton, A 1978 The Northern Isles: Orkney and Shetland. Tuckwell Press (reprinted 1997).

Fojut, N 1994 A Guide to Prehistoric and Viking Shetland, 3rd edn. Lerwick.

Forster, A K in prep 'Bayanne Steatite Report: Vessels and other objects' in Moore, H \& Wilson, $\mathrm{G}$ in prep Excavations at Bayanne, Sellafirth, Yell, Shetland. Shetland Amenity Trust Monogr Ser, Lerwick. 
Forster, A K \& Sharman, P M in prep 'Steatite use in early prehistoric Shetland: from the Neolithic to the Early Iron Age' in Turner, V E \& Forster, A K (eds) in prep Shetland Steatite [provisional title], Shetland Amenity Trust Monogr Ser, Lerwick.

Grant, W G 1937 'Excavation of Bronze Age burial mounds at Quandale, Rousay, Orkney', Proc Soc Antiq Scot 71 (1936-7), 72-84.

Grant, W G 1939 'Excavations on behalf of HM Office of Works at Taiverso Tuick, Trumland, Rousay', Proc Soc Antiq Scot 73 (1938-9), 155-66.

Hamilton, J R C 1956 Excavations at Jarlshof, Shetland. HMSO, Edinburgh.

Hedges, M E 1977 'The excavation of the Knowes of Quoyscottie, Orkney: a cemetery of the first millennium BC', Proc Soc Antiq Scot 108 (1976-7), 130-55.

Henshall, A S 1961 'Appendix: The finds', 40-45 in Calder, C S T'Excavations in Whalsay, Shetland, 1954-5', Proc Soc Antiq Scot 94 (1960-1), 28-45.

Highley, D E 1974 Talc. Institute of Geological Sciences Mineral Resources Dossier No 10, HMSO, London.

Holck, P 1986 Cremated Bones: A Medical-Anthropological Study of Archaeological Material on Cremation Burials. Anthropologiske Skrifter 1, Anatomical Institute, University of Oslo.

Holden, J L, Phakey, P P \& Clement, J G 1995 'Scanning electron microscope observations of heat-treated human bone', Forensic Science International 74, 29-45.

Hunter, J R 1996 Fair Isle: The Archaeology of an Island Community. NTS \& HMSO, Edinburgh.

Hunter, J R \& Dockrill, S J 1991 Loth Approach Road, Sanday, Orkney: an Archaeological Evaluation. Bradford University Archaeological Management and Consultancy Services.

Jane, F W 1970 The Structure of Wood, 2nd Edn, Black, London.

Jones, R, Bassiakos Y, Bray I, Ellam R, Kilikoglou $\mathrm{V}$, Olive V \& Sanderson D forthcoming 'A new protocol for the chemical characterisation of steatite - two case studies in Europe: the Shetland Islands and Crete', J Arch Sci.

Lamb, R 1980 Sanday and North Ronaldsay. The Archaeological Sites and Monuments of Orkney 11, Royal Commission on the Ancient and Historical Monuments of Scotland, Edinburgh.

McKinley, J I 1993 'Bone fragment size and weights of bone from modern British cremations and the implications for the interpretation of archaeological cremations', Intl J Osteoarchaeology 3, 283-7.

McKinley, J I 1994 'A pyre and grave goods in British cremation burials; have we missed something?', Antiquity 68, 132-4.

McKinley, J I 1996 Linga Fiold, Sandwick, Orkney; Human Bone Report with Discussion of Pyre Technology and Ritual. Unpublished report on behalf of GUARD, Glasgow.
McKinley, J I 1997 ‘Bronze Age barrows and funerary rites and rituals of cremation', Proc Prehist Soc $63,129-45$.

McKinley, J I \& Kibble, H 1999 'Human cremation burials' in Dalland, C, 1999, 400-2.

McSweeney, K 1995 'Report on cremated bone' in Smith, A N 'The excavation of Neolithic, Bronze Age and Early Historic Features near Ratho, Edinburgh', Proc Soc Antiq Scot 125, 69-138.

Metcalf, P \& Huntington, R 1993 Celebrations of Death:The Anthropology of Mortuary Ritual, 2nd edn. Cambridge University Press, Cambridge.

Milles, A 1994 'Taphonomy of mollusca from Tofts Ness, Sanday, Orkney', in Dockrill et al 1994, 122-5.

Moffat, D \& Buttler, S J 1986 'Rare earth element distribution patterns in Shetland steatite - consequences for artefact provenancing studies', Archaeometry 28, 101-15.

Mykura, W 1976 British Regional Geology: Orkney and Shetland. HMSO, Edinburgh.

Øvrevik, S 1990 'The Second Millennium and After' in Renfrew, C (ed) 1990 The Prehistory of Orkney, 2nd edn. Edinburgh, 131-49.

Petrie, G 1870 'Notice of excavations and discovery of cists, containing large stone urns, in Stronsay, Orkney', Proc Soc Antiq Scot 8 (1868-70), 347-51.

Photos-Jones, E 1999 The Technical Characterization of Skara Brae Cramp. SASAA No 38.

Photos-Jones, E 2001 The Cramp of the Dead: the Technical Characterization of the Crantit Farm, Orkney, Cist vitrified fuel ash slag. SASAA No 71.

Photos-Jones, E 2003a Technical Characterization of Vitrified Fuel Ash Slag (VFA), from Kewing Cist, Mainland, Orkney. SASAA No 69.

Photos-Jones, E 2003b Technical Characterization of Vitrified Fuel Ash Waste (VFAW), from Knowes of Trotty, Sanday, Orkney. SASAA No 101.

Photos-Jones E, Hall, A J, Ballin Smith, B \& Jones $\mathrm{R} \mathrm{E}$ in preparation 'The Cramp of the Dead': Vitreous Fuel Ash Waste from Prehistoric Funerary Contexts as a Repository of Cremated Bone.

Reinhard, K J \& Fink, T M 1994 'Cremation in Southwestern North America: aspects of taphonomy that affect palaeopathological analysis', $J$ Archaeol Sci 21, 597-605.

Ritchie, G \& Ritchie, A 1974 'Excavation of a barrow at Queenafjold, Twatt, Orkney', Proc Soc Antiq Scot 105 (1972-4), 33-40.

Roberts, G F 1865 'On the discovery of large kistvaens on the "Muckle Heog" in the Island of Unst (Shetland), containing urns of chloritic schist', Mem Anthrop Soc London 1 (1863-4), 296-8.

Roberts, J A1998 The Cremated Bone from Fordhouse Barrow, House of Dun. Unpublished Report for St. Andrews Heritage Services.

Roberts, J A 2000 Cremated Remains from Gitterptten and Varme Dale, Orkney. Unpublished report by GUARD for ARCUS. 
Schoch, W H, Pawlick, B \& Schweingruber, F H 1988 Botanical Macro-Remains: An Atlas for the Determination of Frequently Encountered and Ecologically Important Plant Seeds. Paul Haupt, Berne.

Schweingruber, F H 1990 Anatomy of European Woods. Paul Haupt, Berne.

Sharman, P M 1999 The soapstone urn from Mound 6 at Linga Fiold, Lyking, Mainland Orkney. Unpublished report for the Orkney Barrows Project.

Sharman, P M 2000 'Steatite and other fine stone objects' in Downes, J \& Lamb, R Prehistoric Houses at Sumburgh in Shetland: Excavations at Sumburgh Airport 1967-74, 65-8, 82-7. Oxbow Books, Oxford.

Sharman, P M in prep 'Steatite funerary urns in the early prehistoric Northern Isles' in Turner, V E \& Forster, A K (eds) Shetland Steatite [provisional title], Shetland Amenity Trust Monogr Ser, Lerwick.

Sheridan, A 2003 'New dates for Scottish Bronze Age cinerary urns: results from the National Museums of Scotland Dating Cremated Bones Project', in Gibson, A (ed) Prehistoric Pottery: People, Pattern and Purpose, 201-26. Archaeopress, Oxford (Br Archaeol Rep, Int Ser 1156).

Sheridan, A forthcoming 'New information on an old find: an Early Historic steatite urn from Orkney', Archaeologia Aeliana.

Shipman, P, Foster, G \& Schoeninger, M 1984 'Burnt bones and teeth: an experimental study of colour, morphology, crystal structure and shrinkage', $J$ Archaeol Sci 11, 307-25.

Simpson, I A 1998 'Early land management at Tofts Ness, Sanday, Orkney: the evidence of thin section micromorphology', in Mills, C M \& Coles, $\mathrm{G}$ (eds) Life on the Edge: Human Settlement and Marginality, Symposia of the Association for Environmental Archaeology 13, Oxford (Oxbow monogr 100), 91-8.

Smith, A N in prep 'The steatite vessel fragments from Tofts Ness, Sanday, Orkney', in Dockrill, S J, Bond, J M, Nicholson, R A \& Smith A N Investigations on Sanday Volume II: The Tofts Ness Peninsula. Edinburgh (Soc Antiq Scot monogr ser).

Smith, H \& Mullville, J 2003 'Resource management in the Outer Hebrides: an assessment of the faunal and floral evidence from archaeological investigations' in Housley, R A \& Coles, G (eds) Atlantic Connections and Adaptations: Economies, Environments and Subsistence in Lands Bordering the North Atlantic. Symposia of the Association for Environmental Archaeology 21, Oxbow Books, Oxford.

Stace, C 1997 New Flora of the British Isles, 2nd edn. Cambridge University Press, Cambridge.

Stapleton, C P \& Bowman, S G E 2005 'An examination of the cramp from Barnhouse and Mouseland, Mainland, Orkney' in Richards, C (ed) Dwelling Among the Monuments: the Neolithic Village of Barnhouse, Maeshowe Passage Grave and Surrounding Monumnets at Stenness,Orkney. McDonald Institute, Cambridge, 381-4.

Stuiver, M, Reimer, P J, Bard, E, Beck, J W, Burr, G S, Hughen, K A, Kromer, B, McCormac, G, van der Plicht, J \& Spurk, M 1998 'INTCAL98 Radiocarbon Age Calibration, 24,000-0 cal BP', Radiocarbon 40(3), 1041-83.

Ubelaker, D H 1989 Human Skeletal Remains Excavation, Analysis, Interpretation, 2nd Edn. Taraxacum, Washington. 